\title{
REVIEWS
}

\section{Advances in combating fungal diseases: vaccines on the threshold}

\author{
Jim E. Cutler*, George S. Deepe Jr" and Bruce S. Klein ${ }^{\S}$
}

Abstract | The dramatic increase in fungal diseases in recent years can be attributed to the increased aggressiveness of medical therapy and other human activities. Immunosuppressed patients are at risk of contracting fungal diseases in healthcare settings and from natural environments. Increased prescribing of antifungals has led to the emergence of resistant fungi, resulting in treatment challenges. These concerns, together with the elucidation of the mechanisms of protective immunity against fungal diseases, have renewed interest in the development of vaccines against the mycoses. Most research has used murine models of human disease and, as we review in this article, the knowledge gained from these studies has advanced to the point where the development of vaccines targeting human fungal pathogens is now a realistic and achievable goal.

*Departments of Pediatrics and Microbiology, Immunology and Parasitology, Louisiana State University Health Sciences, and Research Institute for Children at Children's Hospital, New Orleans, Louisiana, 70118 USA. ${ }^{\ddagger}$ Division of Infectious Diseases, University of Cincinnati College of Medicine, Cincinnati, Ohio, 45267-0560 USA. \$Departments of Pediatrics, Internal Medicine, and Medical Microbiology and Immunology and the University of Wisconsin Comprehensive Cancer Center, University of Wisconsin School of Medicine and Public Health Madison, Wisconsin, 53792 USA. e-mails: jcutler@chnola-research.org. deepegs@ucmail.uc.edu; bsklein@wisc.edu doi:10.1038/nrmicro 1537 Published online

11 December 2006
For many years, the concept of developing vaccines against fungal diseases attracted little interest, but this has changed in the past fifteen years (reviewed in REFS 1-6) because of the dramatic increase in the incidence rates of fungal diseases worldwide. Carbohydrate and, especially, protein antigens that exert protective immunity against various fungal diseases have now been identified. Fungal carbohydrates can induce the production of antibodies that enhance host resistance in many ways and, fuelled by advances in cellular and molecular biology, numerous fungal proteins that trigger T-cell-mediated immunity and that are immunogenic in murine models of fungal disease have been identified (TABLE 1). A vaccine based on one or more of these candidate antigens could prevent disease by inducing protective antibodies, T-cell-mediated immunity or a combination of both of these aspects of the host immune response. In this Review, we will assess the state of fungal vaccine development, both prophylactic and therapeutic.

\section{Overview of the immune response to fungi}

Successful resolution of the diseases caused by pathogenic fungi is crucially dependent on the coordinated interactions of many constituents of the host immune response. The host response to these organisms varies, as would be expected for such a heterogeneous group of pathogens, which differ morphologically, genetically and biochemically. Therefore, the effector molecules and cells that are important for combating opportunistic fungi such as Candida and Aspergillus spp. are less important for primary pathogens such as Coccidioides spp. and Histoplasma capsulatum (BOX 1).
The innate response to fungi. As with all pathogens, the innate immune system is a crucial determinant in the antifungal response (FIG. 1). Host cell-surface receptors are instrumental in the initial contact with fungi, which can bind to or engage several receptors, including Toll-like receptors, dectin-1, the mannose receptor, Fc receptors and integrins ${ }^{7-13}$. Engagement of these receptors by fungi such as Candida spp. can lead to the release of inflammatory mediators and the activation of innate immunity or, in the case of $H$. capsulatum, inhibition of innate immunity ${ }^{14-16}$. Binding of $H$. capsulatum to the CD11b cell-surface glycoprotein suppresses the production of interleukin 12 (IL-12) by macrophages and results in a suboptimal or absent T-helper $1\left(\mathrm{~T}_{\mathrm{H}} 1\right)$ response ${ }^{14}(\mathrm{BOX} 2)$.

Neutrophils, macrophages and dendritic cells (DCs) constitute the cellular effectors of innate immunity against fungal pathogens. Neutrophils are essential for host defence against Candida, Fusarium and Aspergillus spp., and their absence is a major risk factor for the acquisition of infection and development of disease $^{17}$. Although neutrophils seem to be essential, they can also impair the host response. For example, murine neutrophils expressing the CD80 cell-surface marker inhibit the expression of the $\mathrm{T}_{\mathrm{H}} 1$ response in an experimental model of candidiasis ${ }^{18}$, and depletion of mouse neutrophils in an experimental model of cryptococcosis enhances rather than diminishes protective immunity ${ }^{19}$. The main contribution of neutrophils resides in their phagocytic and microbicidal functions, but they can produce cytokines and chemokines that can modulate the protective immune response. 


\section{Table 1 | Fungal protective antigens and immunogens that rely on antibody and/or cell-mediated immunity}

Antigen or immunogen

Candida spp.

$\beta$-1,2-linked mannobiose and mannotriose

$\beta$-1,3-linked glucan

Heat shock protein 90 (Hsp90); epitope LKVIRK

of $\mathrm{Hsp} 90$

Antibody idiotope specific for yeast killer toxin

Unknown, possibly protein

Secreted aspartyl proteinase

Mannoprotein 65

Agglutinin-like sequence 1 and 3

Aspergillus spp.

$\beta$-1,3-linked glucan

Aspf16

\section{Cryptococcus neoformans}

Glucuronxylomannan (GXM) and GXM peptide mimotopes

Polysaccharide deacetylase

\section{Coccidioides spp.}

Proline-rich antigen (also known as Antigen 2)

ELI antigen (unknown function)

Aspartyl transferase

Gel-1 ( $\beta$ 1,3 glucosyltransferase)

Urease

Peroxisomal matrix protein

Chimeric proline-rich antigen plus Coccidioides-specific antigen

Chimeric protein-aspartyl proteinase, phospholipase B and $\alpha$ mannosidase

Live attenuated strain harbouring deletion of two

chitinase genes

\section{Histoplasma capsulatum}

Histone-H2B-like protein

Hsp60

$\mathrm{H}$ antigen

80-kilodalton antigen

Sec31 homologue

\section{Blastomyces dermatitidis}

BAD1

BAD1-deleted live attenuated strain

\section{Pneumocystis carinii}

Major surface glycoprotein (also known as gp120)

p55

Kexin

\section{Paracoccidioides brasiliensis}

Proposed mechanism of protection

Antibody; antibody-dependent complement opsonization

Antibody; possibly directly candidacidal

Antibody; possibly by neutralizing effects of $\mathrm{Hsp} 90$ on host proteins

143,156

Anti-idiotypic antibody; directly candidacidal

Antibody (mAb C7); antibody-dependent complement opsonization and possibly directly candidacidal

Antibody

Antibody

Unknown

Antibody; possibly directly candidacidal

Unknown

Antibody; enhance effectiveness of CMI by various mechanisms

IFN- $\gamma$ dependent

IFN- $\gamma$ dependent

Unknown

Unknown

Unknown

Unknown

Unknown

Unknown

Unknown

Unknown

G. Cole, personal communication

mAb; unknown mechanism

Induction of IFN- $\gamma$ and IL-10; CD4 ${ }^{+}$T-cell dependent

Unknown

Unknown

Unknown

Unknown

CD4 ${ }^{+} T$ cells, $C D 8^{+} T$ cells and select $T_{H} 1$ cytokines, depending on host's immune status

BAD1, Blastomyces adhesin 1; CMI, cell-mediated immunity; ELI, expression library immunization; IFN, interferon; IL, interleukin; mAb, monoclonal antibody; $\mathrm{T}_{\mathrm{H}} 1$, T-helper 1. 


\section{Box 1 | Fungal pathogens: primary pathogens and opportunists}

Medically important fungi can be categorized as opportunists or primary pathogens. The opportunists rarely cause disease in an immunocompetent host whereas the primary pathogens do. The opportunists are Candida spp., Aspergillus spp., Cryptococcus neoformans and Pneumocystis jirovecii. The primary pathogens referred to in this review are Histoplasma capsulatum, Coccidioides immitis, Coccidioides posadasii and Blastomyces dermatitidis. However, the primary pathogens can become opportunists when host immunity wanes. The distinction between primary pathogen and opportunist is not welldefined, although some have argued that susceptibility of the mould form to toxic oxygen radicals might distinguish a primary pathogen from an opportunist ${ }^{145}$. Generally, exposure of the host organisms to non-lethal challenge with a primary pathogen leads to resolution of infection. However, in the case of $H$. capsulatum or B. dermatitidis, the organism can establish a dormant state and reactivate spontaneously or when the host's immune system is impaired. Recovery is dependent on the activation of a T-helper $1\left(T_{H} 1\right)$ response. The opportunists manifest heightened virulence only when the host's defence mechanisms are impaired.

Toll-like receptors

A family of receptors present on mammalian cells that recognize pathogen-associated molecular patterns.

Dectin-1

A C-type lectin pattern recognition receptor mainly found on phagocytes that is involved in the innate immune response to fungal pathogens by recognizing $\beta$-glucans.

Mannose receptor

A lectin-like pattern recognition receptor expressed on the surface of macrophages, endothelial cells and immature dendritic cells that recognizes microbial glycans.

\section{Fc receptor}

Surface molecules on various cells that bind to the Fc regions of immunoglobulins, thereby initiating effector functions.

\section{Integrins}

A large family of heterodimeric transmembrane glycoproteins that function as adhesins, mediating adhesion to other cells, either microbial or host.

\section{Complement}

Proteins found in the serum that can be activated by proteolytic cleavage, resulting in the generation of molecules that can bind to specific surface receptors on mammalian cells and can lead to the formation of a terminal cell-lytic complex in the membrane of a target cell. Complement fragments such as those derived from $\mathrm{C3}$ and $\mathrm{C} 5$ have important proinflammatory properties, such as vasodilation, chemotaxis and opsonization
Macrophages are an important phagocytic population in host defence against fungi. Not only can they ingest organisms that have been opsonized with antibody, complement or collectins, they can also phagocytose unopsonized fungal elements through recognition receptors such as the integrins ${ }^{7,8}$. This phagocytic population has many functions, including fungistatic and fungicidal activities, the production of cytokines and chemokines, and antigen presentation to both $C D 88^{+} \mathrm{T}$ cells and $\mathrm{CD} 4^{+}$ $T$ cells. For some intracellular fungal pathogens, such as Cryptococcus neoformans, H. capsulatum and Blastomyces dermatitidis, their intracellular location protects them from host defences, and these organisms thrive within macrophages.

Immature DCs can engulf and kill several fungal species $^{20-22}$. One mechanism of killing is the increased mobilization of phagolysosomes, which generates an inhospitable environment for fungal survival ${ }^{22}$. Most often, ingestion of fungi or fungal antigens leads to DC maturation and increased efficiency of fungal antigen presentation. DCs can also distinguish between different fungal morphotypes. These cells ingest both the yeast and hyphal forms of Candida albicans and the conidial and hyphal forms of Aspergillus spp. ${ }^{21}$ DCs use distinct receptors to recognize each form of a particular fungus, thereby activating different signalling pathways with distinct functional consequences.

The non-cellular effectors of innate immunity comprise collectins, complement and natural antibodies. These molecules mediate opsonization and therefore promote the ingestion of fungi by phagocytes. One member of the collectin family, pentraxin 3 , is necessary for the response to Aspergillus spp. ${ }^{23}$, and the pulmonary collectins surfactant proteins A and D not only cause aggregation of fungi but also have fungicidal activity ${ }^{24}$. The fate of opsonized fungi can differ from that of unopsonized organisms, probably because in phagocytes, opsonized fungi traffic through a different pathway to opsonized organisms.
Skin

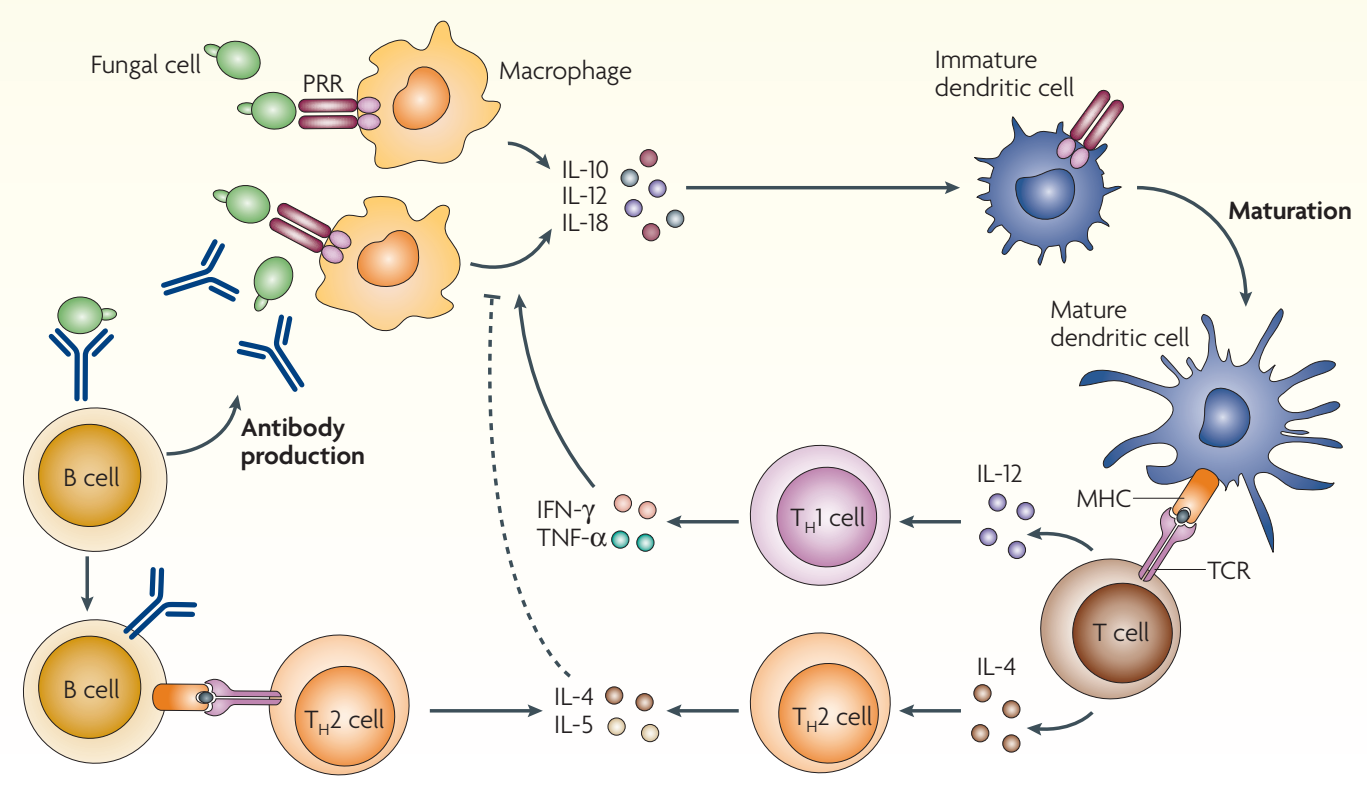

Figure 1 | The host response to fungi. The figure shows the complex interaction between fungi or fungal antigens and the host immune response. Dendritic cells (DCs) process and present antigens through class I or class II major histocompatibility complex (MHC) molecules to antigen-specific clones of T cells endowed with the capacity to recognize the peptide epitopes through specific T-cell receptors (TCR). The production of interleukin (IL)-12 by DCs leads to the outgrowth of T-helper $1\left(\mathrm{~T}_{H} 1\right)$ cells that produce interferon- $\gamma\left(\right.$ IFN- $\gamma$ ), tumour necrosis factor- $\alpha$ (TNF- $\alpha$ ) or both. The $T_{H} 1$ response leads to enhanced fungistatic and fungicidal activities by phagocytes. The induction of IL-4 (and failure to produce IL-12) by DCs leads to $\mathrm{T}_{\mathrm{H}} 2$ response, which blunts the generation of protective immunity. PRR, protein recognition receptor. 


\section{Box $2 \mid T_{\text {The }} T_{H} \mathbf{1} / T_{H} 2$ response in fungal diseases.}

The induction of a dominant T-helper $1\left(\mathrm{~T}_{\mathrm{H}} 1\right)$ response is crucially important in the host response to naturally acquired infection with pathogenic fungi. The $\mathrm{T}_{H} 1$ cytokines IL-12, interferon (IFN)- $\gamma$ and tumour necrosis factor (TNF)- $\alpha$ are required for the clearance of infection with most, if not all, of these pathogens, especially in primary disease ${ }^{26}$. By contrast, progressive disease in immunodeficient or susceptible mice is associated with a shift in the balance between $\mathrm{T}_{\mathrm{H}} 1$ and $\mathrm{T}_{\mathrm{H}} 2$, towards the $\mathrm{T}_{\mathrm{H}} 2$ response ${ }^{26}$. The latter is characterized by upregulation in IL-4, IL-5 and IL-10, an increase in tissue eosinophils and elevated levels of IgE. Neutralization of IL-4, IL-5 and IL-10 in vivo can sometimes restore protective immunity ${ }^{84,146,147}$. A dominant $\mathrm{T}_{\mathrm{H}} 2$ response is evoked when the host fails to synthesize sufficient amounts of $\mathrm{T}_{\mathrm{H}} 1$ cytokines such as IFN- $\gamma$ and TNF- $\alpha^{84,148,149}$. For example, the neutralization of TNF- $\alpha$ or granulocyte-macrophage colonystimulating factor (GM-CSF) in mice infected with Histoplasma capsulatum results in a sharp increase in the levels of IL-4 and IL-10 (REFS 146,147). Both cytokines block the expression of a protective response. Aside from the absence of a cytokine, $\mathrm{a} \mathrm{T}_{H} 2$ response can also be elicited if a receptor for a $\mathrm{T}_{\mathrm{H}} 1$ cytokine (for example, the IFN- $\gamma$ receptor) is blocked or absent ${ }^{150}$. However, the elaboration of at least some $\mathrm{T}_{H} 2$ cytokines also helps to balance the immune response.

\section{Collectins}

C-type lectins that have a collagen-like domain, including mannose-binding lectin and the two mucosal-associated proteins, surfactant protein A and $\mathrm{D}$.

\section{CD8 $+\mathrm{T}$ cell}

A subpopulation of $\mathrm{T}$ cells that express the $\mathrm{CD} 8$ receptor. $\mathrm{CD} 8{ }^{+} \mathrm{T}$ cells recognize antigens that are presented on the surface of host cells by major histocompatibility complex class I molecules, leading to their destruction, and are therefore also known as cytotoxic $\mathrm{T}$ cells.

\section{$\mathrm{CD}^{+}+\mathrm{T}$ cell}

A subpopulation of $\mathrm{T}$ cells that express the CD4 receptor and respond to antigens presented on the surface of host cells that have major histocompatibility complex class II molecules. Two distinct subsets of activated $\mathrm{CD} 4^{+} \mathrm{T}$ cells have been described. T-helper $1\left(T_{H} 1\right)$ cells produce interferon $\gamma$, tumournecrosis factor $\alpha$ and interleukin (IL-) 12, and support cellmediated immunity. T 2 cells produce IL-4, IL-5 and IL-13, support humoral immunity and downregulate $T_{H} 1$ responses.

\section{Phagolysosome}

An intracellular vesicle that results from the fusion of phagosomes that enclose ingested extracellular material and lysosomes, which contain lytic enzymes.

\section{Opsonization}

The deposition of antibody or complement products on the surface of microorganisms that can facilitate recognition and uptake.
The adaptive response to fungi. For all fungi, T-cell activation is a crucial element in the development of optimal protective immunity (FIG. 1). Both $\mathrm{CD} 4^{+}$and $\mathrm{CD}^{+} \mathrm{T}$ cells are necessary for the elimination of fungal pathogens; however, in the primary stages of disease, for many fungi the presence of $\mathrm{CD} 4^{+} \mathrm{T}$ cells is vital for the survival of the host, whereas $\mathrm{CD} 8^{+} \mathrm{T}$ cells are necessary to restrict infection ${ }^{25}$. In secondary disease, each T-cell subset is dispensable, therefore, the absence of either $\mathrm{CD} 4^{+}$or $\mathrm{CD}^{+} \mathrm{T}$ cells does not lead to overwhelming disease.

The main effector mechanisms of $\mathrm{T}$ cells are cytotoxicity and cytokine secretion. The role of cytotoxicity in host defence against fungi is not well delineated, however the activity of cytokines is better understood. For all of the pathogenic fungi, a $\mathrm{T}_{\mathrm{H}} 1$ response is the dominant adaptive response ${ }^{26-28}$ (BOX 2). The absence of the $\mathrm{T}_{\mathrm{H}} 1$ cytokines interferon (IFN)- $\gamma$ or tumour necrosis factor (TNF)- $\alpha$ leads to overwhelming disease. The $\mathrm{T}_{\mathrm{H}} 2$ response is often associated with a subversion of the host response to fungi. Increases in the $\mathrm{T}_{\mathrm{H}} 2$ cytokines IL-4 and IL-10 are commonly observed in progressive disease, and neutralizing their activity restores protective immunity ${ }^{26}$. One possible beneficial effect of $\mathrm{T}_{\mathrm{H}} 2$ cytokines is that they dampen the damage associated with an exuberant inflammatory response.

Nearly all fungi elicit an antibody response, yet there is little evidence that these antibodies modulate pathogenesis. The acquisition of antibodies to C. albicans and C. neoformans occurs early in life, yet there is little evidence that these antibodies either confer protection or exacerbate disease ${ }^{29}$. The generation of numerous antibody specificities in response to infection and disease results in a heterogeneous polyclonal antibody population. Individually, these antibodies might enhance immunity, dampen immunity or exert no effect. The algebraic sum of their activities defines the ultimate function of the antibody response in vivo. The fact that polyclonal antibodies do not confer protection does not exclude the possibility that protective antibodies are generated; identifying those protective antibodies often requires examination at the monoclonal level.
Evidence for protective antibodies against fungal disease. Why has a role for antibodies in host defence against fungal disease been questioned? As alluded to above, one reason is that patients typically have antifungal antibodies before and/or during disease. Experimentally, only a smattering of reports have shown evidence of beneficial antibodies being generated following immunization with whole fungal cells ${ }^{30,31}$. Evidence now abounds, however, that protective antibodies must be of the correct specificity, isotype and titre (for examples, see REFS 32-34). The enormous antigenic complexity of fungal cells probably precludes the production of antibodies that fulfil these criteria whether during colonization, tissue invasion or immunization with whole cells.

The most compelling data for a role for antibodies in protective immunity against fungal diseases come from studies on the opportunistic mycoses, especially cryptococcosis and candidiasis, but also aspergillosis. The aetiological agents in vivo are primarily extracellular, but $C$. neoformans, the cause of cryptococcosis, is considered a facultative intracellular pathogen ${ }^{35}$. Research has focused on fungal cell-surface carbohydrates, including the capsular material of C. neoformans and the cell-wall polysaccharides of Candida and Aspergillus species (discussed in more detail in the next section).

Antibody protection can also occur through recognition of specific proteins, such as heat shock protein 90 (Hsp90) and mannoprotein 65 (MP65) in C. albicans and the histone-H2B-like surface protein found on tissue-phase yeast cells of the endemic fungus H. capsulatum (TABLE 1). The latter finding, based on the isolation of a protective monoclonal antibody ${ }^{36}$, is intriguing because the yeast form of $H$. capsulatum is found in macrophages, implying that an appropriate antibody response could augment host defences against intracellular pathogens ${ }^{37}$. Some researchers have raised the question of whether protective antibodies also function against other endemic dimorphic fungi ${ }^{38}$, such as Coccidioides spp., B. dermatitidis, Paracoccidioides brasiliensis, Sporothrix schenckii and Penicillium marneffei.

A role for antibodies in defence against fungal disease might seem to be in conflict with the underlying $\mathrm{T}_{\mathrm{H}}$ 1-directed response that is the most widely accepted explanation for host-acquired specific immunity against fungi. On closer examination, however, in at least one case, $\mathrm{T}_{\mathrm{H}} 2$-derived antibodies have a protective effect by somehow augmenting cell-mediated immunity ${ }^{39}$. In other cases, antibodies can function as opsonins, promoting fungal ingestion and even killing by phagocytes, and several antibodies are directly fungicidal ${ }^{40-47}$ (TABLE 1). These kinds of activities are complementary, rather than exclusive, to cell-mediated mechanisms. The central importance of granulocytes and macrophages in innate defence against opportunistic fungal pathogens, and of activated neutrophils and macrophages against fungi in general, is consistent with an expectation that opsonic antibodies facilitate host defence. Likewise, fungicidal antibodies acting independently of additional host factors would be of obvious benefit to the host. 


\section{Box 3 | Adjuvants and conjugates}

An adjuvant can be defined as a substance that can enhance the antigenicity of an immunogen. A conjugate is a substance that can be fused with an immunogen and promotes its effect. The injection of a protein or carbohydrate into a host often does not lead to an immune response as assessed by T- or B-cell activation. Under these circumstances, adding an adjuvant or conjugating an immunogen to an antigen can substantially elevate the potency of the protein or carbohydrate antigen.

In vaccinology, two adjuvants have been used over the years. In mice, Freund's adjuvant consisting of killed Mycobacteria suspended in an oil emulsion was the standard bearer. Although highly useful, this adjuvant is no longer recommended for use in animals. The other adjuvant, alum, has been used in humans for years. However, this adjuvant often elicits a T-helper $2\left(\mathrm{~T}_{\mathrm{H}} 2\right)$ response, which is not the type of response necessary to combat most fungal diseases.

There has not been a systematic study of adjuvants or conjugates in fungal vaccine development. Their use would be limited to material that is non-replicating. CpG DNA, which engages Toll-like receptor 9 (REF. 151) and commercial preparations consisting simply of oil or an admixture of mycobacterial constituents and lipid A have been used. In addition, delivery of carbohydrates in liposomes has also been shown to provoke an antibody response ${ }^{58}$. Heat shock protein 70 has been reported to possess adjuvant activity but its use in fungal vaccines has not been explored ${ }^{152}$. $\beta$-glucan, a constituent of most fungal cell walls, has long been recognized for its potent adjuvant properties ${ }^{153}$.

The use of conjugates is another route to enhance antigenicity. As reported in the text, the glycoconjugate vaccine that fuses the poorly immunogenic $\beta$-glucan laminarin to the diphtheria toxoid CRM 197 is one such example. Here, the toxoid serves as a carrier protein to enhance the immunogenicity of $\beta$-glucan. The glucan-CRM conjugate proved to be immunogenic and protective against Candida and Aspergillus spp. ${ }^{40}$ Multivalent vaccines have been shown to be more potent than single antigens. The linking of two or three antigens or antigenic epitopes confers superior protection in models of coccidioidomycosis ${ }^{103}$. However, this vaccine preparation still requires an adjuvant.

As many antigens from fungi are glycosylated, the influence of the carbohydrate molecule has been unclear. Evidence points to the fact that glycosylation enhances immunogenicity of the model protein ovalbumin, as assessed by T-cell proliferation ${ }^{102}$. Moreover, antigens from Cryptococcus neoformans contain mannose residues and use the mannose receptor for entry ${ }^{9}$. The absence of the receptor sharply reduces the recognition of the antigen. Therefore, entry into the mannose-receptor pathway seems to be an important determinant for subsequent antigen processing and presentation.

One challenge facing investigators interested in vaccine development is developing vaccines that induce protective, rather than non-protective, antibody responses, as discussed below.

\section{Carbohydrate antigens and protective antibodies}

The accessibility of antigens to the immune response, rather than their chemical composition, is a key consideration in selecting a carbohydrate antigen for vaccine development. The major capsular polysaccharide of C. neoformans, glucuronoxylomannan (GXM), conjugated to the tetanus toxoid resulted in anti-GXM protective antibody responses ${ }^{48,49}$, and monoclonal antibodies specific for GXM protect against experimental crypto$\operatorname{coccosis}^{50}$. However, the pleiotropic effects of GXM on host immunity (reviewed in REFS 51,52), and the variable protective responses to GXM-carrier conjugates ${ }^{53}$ (BOX 3), militate against the use of intact GXM in human vaccine development. Coupling a heptasaccharide that is thought to be the major GXM immunodeterminant to a protein carrier induced antibodies against the heptasaccharide $^{53}$. Presumably, the heptasaccharide will not have GXM-like side effects, but this presumption requires testing, as does the question of whether the antibodies are protective (BOX 4). The GXM peptide mimotope P13 conjugated to the tetanus toxoid prolonged the survival of cryptococcal-infected transgenic mice owing to the production of human P13-specific IgG2 (but not IgG1) ${ }^{54}$. The effects of immunoglobulin isotype correlate with the clinical observations, as IgG2 is commonly produced in response to bacterial capsular polysaccharides ${ }^{45}$ and by normal adults in response to GXM, whereas IgG1 is associated with paediatric AIDS patients at risk of developing cryptococcosis ${ }^{55}$.
In C. albicans, short-chain $\beta$-1,2-linked oligomannosides, either as part of the phosphomannan complex that is $N$-linked to cell-wall matrix proteins ${ }^{56}$ or as cell-wall-associated phospholipomannan complexes ${ }^{57}$, are recognized by anti-mannan antibodies that are protective against experimental candidiasis ${ }^{58-60}$. These oligomannosides are produced by $C$. albicans serotype A and B strains, Candida tropicalis, most Candida glabrata strains ${ }^{61,62}$ and Candida lusitaniae $e^{63}$. Antibodies against $\beta$-1,2-linked mannotriose or mannobiose protect mice against hematogenously disseminated candidiasis involving both C. albicans serotypes and C. tropicalis $^{58}$, and protection is expected to be elicited against other species of Candida that constitutively produce $\beta$-1,2-linked oligomannosides. In vitro synthesis of $\beta$-1,2-oligomannosides ${ }^{64}$ has led to the ability to mass produce this epitope ${ }^{65}$ and prototype vaccines consisting of synthetic $\beta$-trimannose coupled to protein carriers have been produced ${ }^{66}$. Normal rabbits produce high antibody titres to a trimannose-tetanus toxoid conjugate and, when rendered immunocompromised, they show enhanced resistance to disseminated candidiasis (David Bundle, personal communication), which is consistent with antibody protection in neutropenic mice ${ }^{67}$. These, and further studies showing the effectiveness of beneficial antibodies against experimental C. albicans vaginal infection of mice ${ }^{68}$, have prompted discussion on the need for a vaccine against candidiasis, including the safety concerns regarding the induction of an immune response that might negatively impact on a fungus that is a member of the human normal microbiota ${ }^{1}$.

Recently, another fungal cell-wall polysaccharide - $\beta$-glucan - has been identified as a possible target for the induction of protective antibodies ${ }^{40}$. This finding 


\section{Box 4 | Immunoglobulin classes or isotypes}

There are five main classes or isotypes of human immunoglobulins (lgs) produced by B cells: $\lg \mathrm{M}, \lg \mathrm{D}, \lg \mathrm{G}, \lg \mathrm{A}$ and $\lg \mathrm{E}$. $\ln$ addition, there are four subclasses of human $\lg G$, namely $\lg G 1, \lg G 2, \lg G 3$ and $\lg G 4$, and two subclasses of $\lg A$. Monomeric $\lg \mathrm{M}$ and $\lg \mathrm{D}$ are antigen receptors on $\mathrm{B}$ cells and, following an encounter with antigen, the $\mathrm{B}$ cells can differentiate into plasma cells that produce and secrete pentameric $\lg \mathrm{M}$, which can be detected in the blood. In the presence of appropriate Thelper $\left(T_{H}\right)$ cell cytokines, these same B cells become stimulated to rearrange the DNA of the genetic elements that code for the $\lg$ heavy chains and shift from being lgM-producing cells to cells that can produce $\lg \mathrm{G}, \lg \mathrm{A}$ or $\lg \mathrm{E}$. In the ontogeny of the immune response, $\operatorname{lgM}$ is the first antibody to appear in the bloodstream following antigenic stimulation. If the antigen has a high density of repeating epitopes, as typified by polysaccharides, which are specifically recognized by the $\mathrm{B}$-cell receptor, $\mathrm{T}_{\mathrm{H}}$ cell interactions are minimal and IgM remains the primary lg class in response to these so-called T-cellindependent type antigens. If the antigen is a protein or a polysaccharide antigen covalently coupled to a protein carrier, these T-cell-dependent antigens require the involvement of $\mathrm{T}_{H}$ cells that secrete cytokines. Depending on the cytokine produced, the $\lg$ response can shift from the $\lg \mathrm{M}$ to the $\lg \mathrm{G}$ subclasses, and to $\lg A$ and $\lg E$. In addition to inducing an $\lg$ class shift, the cytokines promote B-cell clonal expansion, resulting in a heightened or memory-cell response on future encounters with the T-cell-dependent antigen.

Mice also produce the five basic isotypes or classes of $\lg s$, but the subclasses of $\lg G$ are $\lg G 1, \lg G 2 a$ or $\lg G 2 c, \lg G 2 b$ and $\lg \mathrm{G}$. The effector functions of mouse $\lg \mathrm{G}$ subclasses are not directly comparable to human $\lg \mathrm{G}$ subclasses, but there are some important similarities, as pointed out below.

The lg shift that can occur in response to T-cell-dependent antigens is essential from several standpoints ${ }^{154}$. The epitope specificity of the original IgM and subsequent lg shifts that occur within a given B cell remain the same, but the affinity for the epitope can be increased by a process known as affinity maturation. Also, the Fc region of the heavy chains, that is, the part of the lg not directly involved in combining with the epitope, has important effector functions. Whereas the $\mathrm{Fc}$ region of $\lg \mathrm{M}$, $\lg \mathrm{G} 1$ and $\lg \mathrm{G} 3$ in humans, and of $\lg \mathrm{M}$ and $\lg \mathrm{G} 3$ in mice, engenders these $\lg$ s with the ability to activate the classical or antibody-dependent complement activation pathway, $\lg \mathrm{G} 2$ and $\lg \mathrm{g} 4$ of humans and $\operatorname{lgG} 1$ of mice interact poorly with complement ${ }^{154,155}$. IgA is known as secretory antibody as it is found as a proteaseresistant dimer primarily on mucosal surfaces, but it is found as a monomer in the bloodstream and breast milk, and fixes complement only weakly ${ }^{154}$. The Fc region of the $\lg E$ heavy chains is recognized by high-affinity Fce receptors on mast cells and basophils ${ }^{154}$. The combination of antigen with specific lgE adsorbed onto mast cells can result in degranulation of these cells and the release of pharmacologically active mediators of type I (immediate)

hypersensitivity reactions. There are other important effector functions of Igs, such as transplacental passage primarily of $\lg \mathrm{G}$ subclasses; in humans $\lg \mathrm{G} 1$ and $\lg \mathrm{G} 3$ subclasses pass especially well ${ }^{154}$. Therefore, an ideal antibody-inducing vaccine will cause the production of antibodies that must not only have the correct specificity, but are also of the correct class or subclass to ensure protective effector function.

\section{Fc region}

The region of an antibody that is responsible for binding to antibody receptors on cells and the $\mathrm{C} 1 \mathrm{q}$ component of complement.

\section{Type I (immediate)} hypersensitivity reaction An immediate or type I hypersensitivity reaction is a pattern of allergy that can be largely attributed to IgE and a sub-population of immune cells, mast cells and basophils. These cells de if sufficient antigen reacts with IgE antibodies, which function as receptors on the cell's surface, resulting in a range of allergic symptoms. is striking for at least two reasons. First, the discovery was made by immunizing mice with the algal glucan laminarin, indicating that the $\beta$-glucan structure is phylogenetically conserved. Second, glucan is common to many fungi and the antibodies protected mice against experimental candidiasis and aspergillosis. This observation prompted the suggestion that $\beta$-1,3-glucan could be part of a universal antifungal $\operatorname{vaccine}^{40,69}$.

\section{Mechanisms of antibody protection}

Antibodies protect the host from infectious processes by various complementary mechanisms (FIG. 2). The simplest example is direct interaction between the antibody and the foreign material, causing its neutralization. In other cases, additional factors that interact with antibodies include constituents of the innate immune system such as complement and cellular components, most notably neutrophils, monocytes and macrophages. The most complex mechanism, which is the least understood, involves the linking of antibody function to T-cell-dependent immunity.

The oldest recognized protective function of antibodies is toxin neutralization. The formation of an antibody-toxin complex subverts the interaction of the toxin with host-cell receptors. This function is shown by antibody neutralization of clostridial toxins and is dependent on the specific interaction of the antibody-combining site with the toxin ${ }^{70}$. Although this interaction prevents toxin entry into susceptible host cells, recent work on the differential effects of protective antibodies against the $\mathrm{A}$ and $\mathrm{B}$ chains of the toxin ricin, which is an A/B type toxin (as are the diphtheria, cholera and pertussis toxins), indicates that the mechanisms involved in antibody neutralization of toxins could be more complex than simply preventing the binding of the toxin to its receptor ${ }^{71}$. A related mechanism is antibody-mediated viral neutralization; high-affinity binding of antibodies to some virions interferes with their attachment to host receptors, preventing entry of the virions into susceptible host cells ${ }^{72}$.

Antibody-dependent opsonization is another protective mechanism. A capsule characteristically prevents host phagocytic cells from ingesting and killing encapsulated microorganisms, such as Streptococcus pneumoniae ${ }^{73}$. Through a process called opsonization, which has been known for more than a century, capsule-specific IgM and IgG antibodies (BOX 4) promote ingestion of encapsulated microorganisms $\mathrm{s}^{73}$. Protection by antibodies is markedly enhanced in the presence of complement, as ingestion involves both phagocyte Fc receptors, which recognize the heavy chain of $\operatorname{IgG}$, and complement receptors, which recognize the complement molecule $\mathrm{C} 3 \mathrm{~b}$, which is degraded to $\mathrm{iC} 3 \mathrm{~b}$ following deposition or fixation of C3b onto the capsular surface $^{74}$. 
Some infectious organisms, most notably certain Gram-negative bacteria, but not fungi, are lysed following activation and deposition of late-acting complement components (C5b-C9) onto their cell surface. This might occur as a result of direct activation of complement factor C3 by the bacterial surface through the alternative pathway of complement activation, or by activation of complement factor $\mathrm{C} 1$, the classical or antibody-dependent pathway of complement activation that occurs after the antibody reacts with the bacterial cell surface ${ }^{75}$.

Antibodies can have direct microbicidal or microbistatic action on attachment to microbial surfaces. As demonstrated by recent work on fungi (see below), antibodies can directly inhibit the growth of fungal cells following an interaction with the fungal surface. This is an exciting finding because of the potential for the application of pre-formed or vaccine-induced antibodies in immunodeficient patients.

As discussed below, there could be additional ways by which antibodies interact with fungal cells, such as C. neoformans, that somehow promote T-cell-mediated immunity against the fungus. Furthermore, studies on this fungus and parallels found with other intracellular parasites indicate that antibodies might have a role in regulation, both up and down, of inflammatory responses $^{76}$.

Most of our insights into the mechanisms of antibody protection against fungal diseases have been gleaned through controlled studies using monoclonal

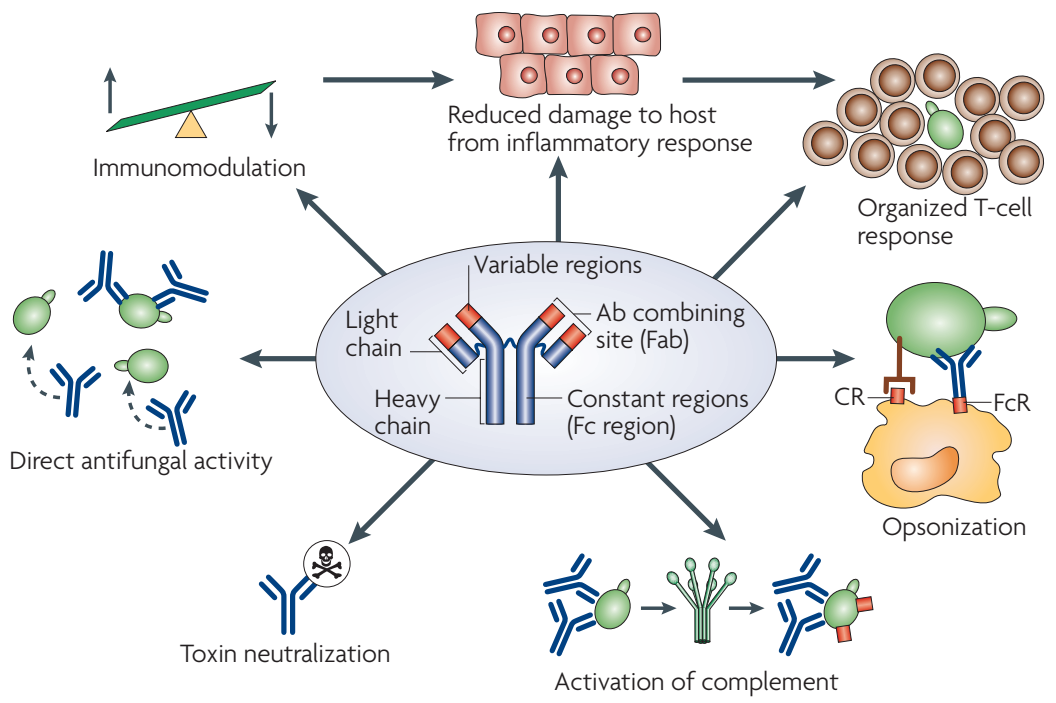

Figure 2 | Antibody-mediated protection against fungal disease. The mechanisms described for antibody-mediated defence against bacterial agents are presumed or proven to also be operative against fungi, including direct antibody (Ab) neutralization of fungal toxins and extracellular enzymes, and direct inhibition of fungal growth. Antibodies can indirectly inhibit fungi by functioning as an opsonin, either alone or in conjunction with complement factor $\mathrm{C} 3$, which is activated and deposited as $\mathrm{C} 3 \mathrm{~b}$ and which degrades to iC $3 \mathrm{~b}$ on the fungal surface. Antibody and complement-coated fungal cells interact with Fc receptors ( $\mathrm{FcR}$ ) and complement receptors (CR) on host phagocytic cell membranes, resulting in prompt ingestion of the fungal cell and which can lead to the death of the ingested fungal cell. In defence against intracellular fungal pathogens, such as Cryptococcus neoformans, protective antibodies seem to have a role in modulating host inflammatory responses and enhancing the organization of T-cell responses. antibodies, rather than attempting to sort out the polyclonal responses generated in vivo. The mechanisms of antibody protection are complex, incompletely understood and vary depending on the antibody isotype and the mycosis (TABLE 1). A few examples have been chosen that show the complexity of this topic.

The role of opsonizing antibodies in protection against encapsulated bacteria, such as S. pneumoniae ${ }^{73}$, leads one to expect that the anti-phagocytic capsular polysaccharide GXM of C. neoformans ${ }^{77}$ would be opsonically neutralized by protective antibodies. In an elegant experiment, a set of three mouse monoclonal antibody isotypes was generated, all derived from the same B-cell parent and with identical GXM specificity but different opsonic activity ${ }^{78}$ (BOX 4). Surprisingly, the mouse isotypes with known high opsonic activity, IgM and IgG3, had low protective activity against murine cryptococcosis and the isotype with low opsonic activity, IgG1, exhibited the highest level of protection ${ }^{78}$. This is consistent with an earlier report ${ }^{79}$, and the data indicate that IgG1-mediated protection occurs through enhanced CD4 ${ }^{+}$T-cell-dependent immunity and increased organization of the cell-mediated inflammatory response ${ }^{39}$. Certain IgM antibodies specific for GXM can also be protective, possibly by altering the structure of the capsule and preventing sloughing of GXM, while at the same time having non-complement-dependent opsonic activity ${ }^{10}$.

The anti-mannan antibody-mediated response against experimental candidiasis, on the other hand, depends on the activation of complement and the rapid deposition of complement factor $\mathrm{C} 3$ onto the fungal cell surface $^{46,47}$. In these experiments, $\beta$-1,2-mannotriosespecific IgM and IgG3 showed the highest protection, whereas IgG1 with the same epitope specificity had little or no protective value. Furthermore, protection by the IgM and IgG3 isotypes was dependent on the presence of $\mathrm{C} 3$ in the test mice ${ }^{46}$.

The mechanism of protection conferred by antiglucan antibodies is unknown, but the reported in vitro direct candidacidal activity ${ }^{40}$ is potentially exciting. That is, if antibodies generated by a glucan vaccine are candidacidal in humans, then these antibodies would be expected to benefit all patients, regardless of their immunocompromised condition.

The finding that antibodies directly inhibit the growth of C. albicans is not unique. Antibodies can suppress fungal respiration ${ }^{41}$ and inhibit the yeast-to-hyphal transition ${ }^{41,42}$. An anti-idiotypic antibody specific for a yeast killer toxin is candidacidal ${ }^{43}$, presumably because it has killer toxin activity. The monoclonal antibody C7 (REF. 44) protects mice against candidiasis ${ }^{80}$ apparently by mechanisms similar to antibodies specific for antimannotriose. In addition, however, C7 directly inhibits the growth of C. albicans, but by unknown mechanisms ${ }^{44}$. Of particular interest is the fact that $\mathrm{C} 7$ inhibits isolates of C. lusitaniae, C. neoformans, Aspergillus fumigatus and Scedosporium prolificans ${ }^{44}$, but whether the antibody is active against these agents in vivo is not known. The specificity of C7 has not been defined, but the epitope is resistant to periodate oxidation ${ }^{44}$, suggesting that it is specific for a protein epitope. 


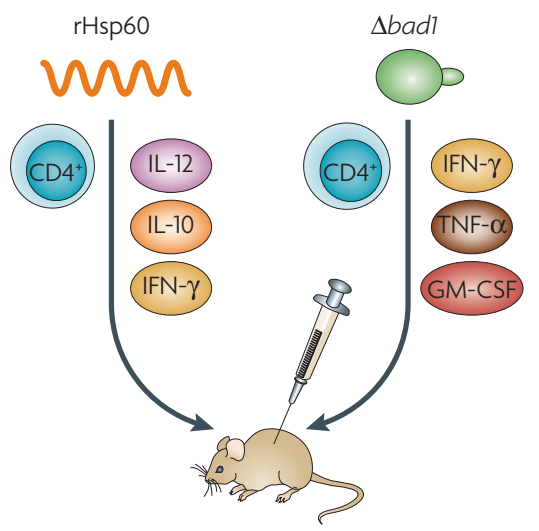

Immunocompetent

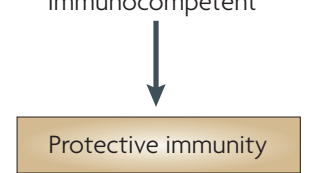

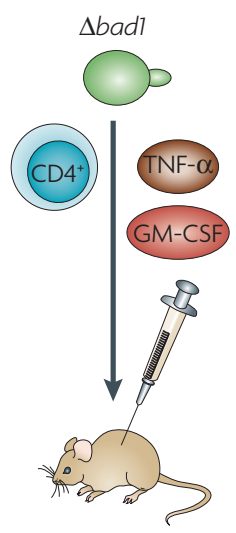

Immunodeficient $\Delta \mathrm{IFN}-\gamma$

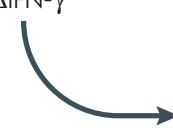

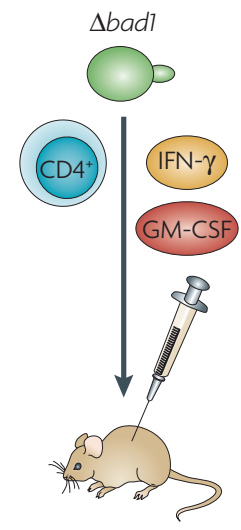

Immunodeficient $\Delta$ TNF- $\alpha$

Protective immunity

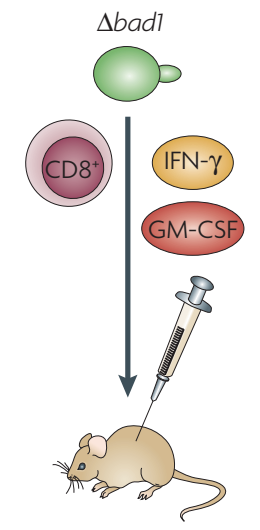

Immunodeficient $\triangle \mathrm{CD}^{+}$ $\Delta$ TNF- $\alpha$

Figure $3 \mid$ The crucial role of the T-helper $1\left(T_{H} 1\right)$ response in vaccine-induced immunity to fungi. In experimental models, recombinant heat shock protein 60 ( $\mathrm{rHsp60}$ ) induces resistance in immunocompetent animals to lethal challenge with Histoplasma capsulatum (left). CD4 ${ }^{+} \mathrm{T}$ cells and the $\mathrm{T}_{\mathrm{H}} 1$ cytokines interleukin (IL)-12, IL-10 and interferon $\gamma($ IFN- $\gamma$ ) are required for this resistance. In immunocompetent animals, the resistance that is induced against experimental blastomycosis by a live attenuated strain of Blastomyces dermatitidis (with a mutation in the Blastomyces adhesin 1 (bad1) gene) has similar requirements for $C D 4^{+} \mathrm{T}$ cells and $\mathrm{T}_{H} 1$ cytokines (right). However, the immune system shows some plasticity and can compensate for the absence of particular cells or cytokines if they are absent during the induction or afferent phase of the vaccine-induced immune response (rather than being eliminated during the expression or efferent phase of the response). For example, immunodeficient animals that lack either $\mathrm{CD}^{+} \mathrm{T}$ cells or selected $\mathrm{T}_{\mathrm{H}} 1$ cytokines at the time of vaccination could control the live attenuated vaccine following subcutaneous administration, and use other $\mathrm{T}$ cells or $\mathrm{T}_{\mathrm{H}} 1$ cytokines to engender vaccine resistance to lethal experimental disease. The absence of IFN- $\gamma$ is compensated by tumour necrosis factor $\alpha$ (TNF- $\alpha$ ) and granulocyte-macrophage colony-stimulating factor (GM-CSF), and the loss of CD4 ${ }^{+} \mathrm{T}$ cells is compensated by $\mathrm{CD} 8^{+}$ T cells that produce type 1 cytokines. $\Delta$, gene knockout or missing owing to antibody depletion.

\section{Protein antigens and cell-mediated immunity}

The principal underlying tenet of vaccine development is that cell-mediated immunity, and in particular $\mathrm{T}_{\mathrm{H}} 1$ mediated immunity, is pivotal in the action of candidate vaccines. Substantial evidence indicates that, for each of the fungi listed in TABLE 1 , the $\mathrm{T}_{\mathrm{H}} 1$ response has a role in resolving disease that is acquired naturally, even for the opportunistic pathogen A. fumigatus, which most often afflicts those in whom neutrophils and macrophages are either absent or functionally impaired. Conversely, the $\mathrm{T}_{\mathrm{H}} 2$ response is largely associated with unrestrained growth of the fungus leading to progressive disease, although the underlying mechanisms have not been fully characterized ${ }^{81-86}$.

Vaccination should therefore direct the immune response to a $\mathrm{T}_{\mathrm{H}} 1$ response, with the induction of IL-12 and IFN- $\gamma$, the two principal cytokines of the $\mathrm{T}_{\mathrm{H}} 1$ response, of paramount importance (FIG. 3). In this regard, vaccination with several protein antigens that confer protective immunity stimulates the production of IL-12 or IFN- $\gamma$ within days of vaccination ${ }^{85,87-92}$. For example, recombinant forms of $\mathrm{Hsp} 60$ from $\mathrm{H}$. capsulatum (but not Coccidioides immitis Hsp60) ${ }^{93}$, the prolinerich antigen Ag2/PRA and urease from Coccidioides spp., and the C. neoformans polysaccharide deacetylase induce the production of these cytokines when analysed ex vivo ${ }^{87,90,91,93}$. However, despite the finding that these cytokines are associated with protective immunity, there is less evidence that they are necessary for vaccine-induced immunity.

Two lines of evidence support the importance of IL-12 and IFN- $\gamma$ in protective immunity against fungal diseases. First, in studies that compared the immune response to a protective fungal protein, H. capsulatum Hsp60, and a non-protective fungal protein, H. capsulatum Hsp70, Hsp70 either induced a lower level of $\mathrm{T}_{\mathrm{H}} 1$ cytokine protection, or did not induce $\mathrm{T}_{\mathrm{H}} 1$ cytokines at all during either immunization or infection ${ }^{87}$. These results indicate that the ability to stimulate the production of IL-12, IFN- $\gamma$ or both could be a reliable surrogate marker for identifying candidate protein antigens for further study. A second approach has been to investigate the necessity of IL-12 and IFN- $\gamma$ for the efficacy of an immunogen in vivo. The neutralization of IFN- $\gamma$ or IL-12 in vivo during vaccination with $H$. capsulatum Hsp60 abolished the protective efficacy of the vaccine ${ }^{87}$. Endogenous IFN- $\gamma$, but not IL-12, was essential for protection elicited by the polysaccharide deacetylase from C. neoformans ${ }^{90}$. Along these lines, protection conferred by immunization with Ag2/PRA requires IL-12, IFN- $\gamma$ and class II, but not class I, major histocompatibility complex (MHC)-restricted $\mathrm{T}$ cells ${ }^{94}$. 

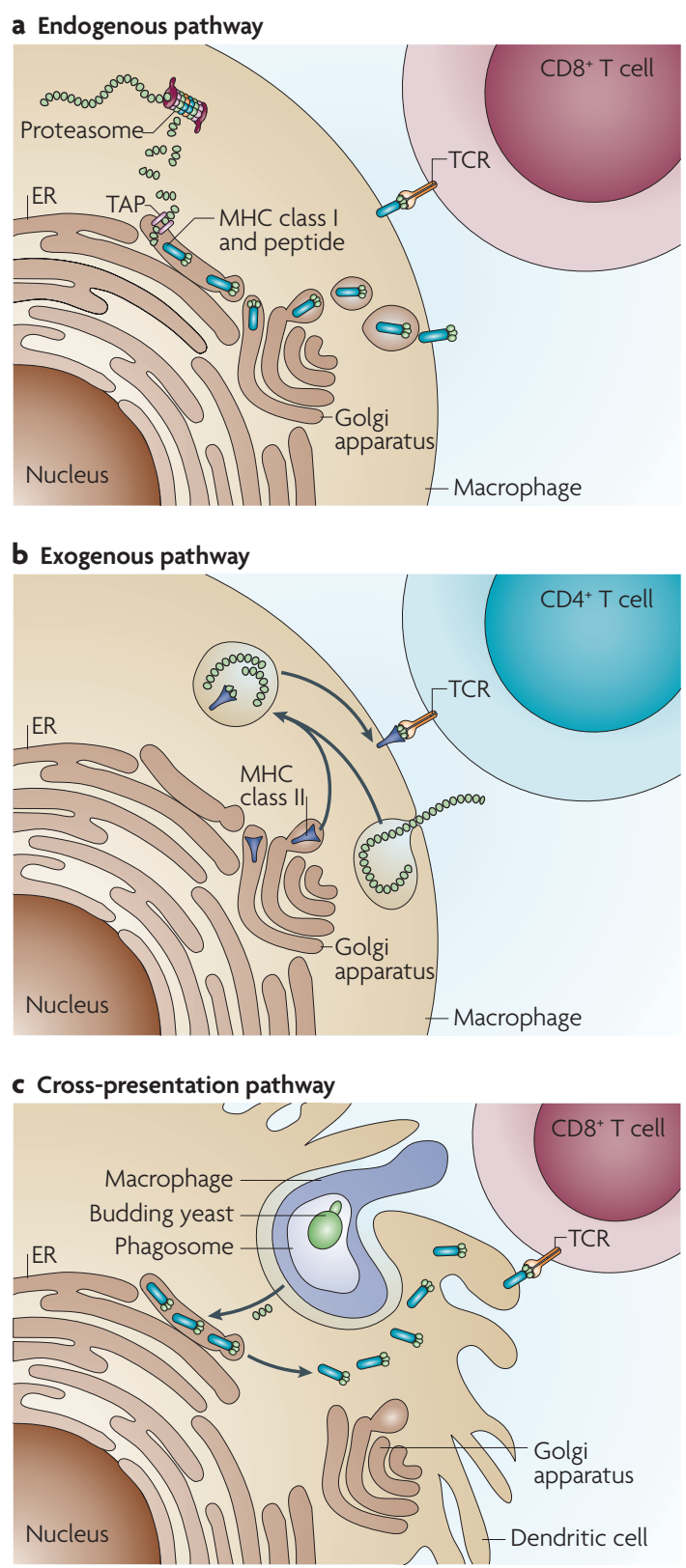

Figure 4 | Antigen processing and presentation to $\mathrm{T}$ cells by major histocompatibility complex (MHC) class I and class II molecules. a | In the endogenous processing pathway, proteins produced in the cytosol of phagocytic or non-phagocytic cells are cleaved in the proteasome into short peptide fragments of 8-10 amino acids and transported into the endoplasmic reticulum (ER) through TAP1 and TAP2, where they bind to MHC class I molecules. The peptide-MHC class I complex is transported through the Golgi apparatus to the cell surface where it is recognized by $\mathrm{CD} 8^{+} \mathrm{T}$ cells. $\mathbf{b} \mid$ In the exogenous processing pathway, antigenpresenting cells such as macrophages or dendritic cells take up extracellular proteins and other microbial products by endocytosis or phagocytosis. In acidified endosomes, MHC class II molecules that have been transported from the Golgi bind fragmented antigenic peptides that are 10-25 amino acids in length. Peptide-MHC class Il complexes are displayed on the cell surface for recognition by $\mathrm{CD} 4^{+} \mathrm{T}$ cells. c| During cross-presentation, dendritic cells take up particles or even phagocytes that have internalized microorganisms. Through an ill-defined process, proteolytically cleaved fragments of antigenic peptide from the phagosome 'cross over' and enter into the MHC class I pathway, probably binding molecules from the ER. These peptide-MHC class I molecules move to the cell surface where they can be recognized by $\mathrm{CD} 8^{+} \mathrm{T}$ cells. TCR, T-cell receptor.
The robust induction of the $\mathrm{T}_{\mathrm{H}} 2$ cytokine IL-10 was an unexpected response to the H. capsulatum Hsp60 protective immunogen, as this cytokine principally functions in the inhibition of inflammation and cellular immunity ${ }^{87}$. Neutralization of IL-10 during immunization abolished the efficacy of the Hsp60 vaccine. The importance of IL-10 has not been thoroughly explored for other fungal vaccines. Recombinant urease from Coccidioides spp. does not induce the transcription of the IL10 gene by T cells although it can promote IL-10 production by macrophages, which are the main generators of this cytokine in response to Hsp60 (REFS 87,93). An increase in $I L 10$ transcription is seen in the lungs of urease-vaccinated mice infected with C. immitis ${ }^{93}$, but the influence on the course of disease is unknown. The importance of IL-10 for the efficacy of vaccinerelated immunity should be contrasted with its role in disease exacerbation ${ }^{27,28}$. A priori, the induction of $\mathrm{T}_{\mathrm{H}} 2$ cytokines should limit the use of a vaccine that must provoke a $\mathrm{T}_{\mathrm{H}} 1$ response to be effective. However, a vaccine that strictly induces a $\mathrm{T}_{\mathrm{H}} 1$ response alone might induce an overly exuberant inflammatory response that can damage the host when the infectious agent is encountered. A vaccine that incorporates both $\mathrm{T}_{\mathrm{H}}{ }^{1-}$ stimulating and $\mathrm{T}_{\mathrm{H}}$ 2-stimulating epitopes could provide a balance between immunity and inflammation.

Protein-bearing antigens ingested by antigen-presenting cells (APCs) most often traffic through the exogenous antigen-processing pathway (FIG. 4), in which the protein is digested and the peptides are displayed on the APC surface in the context of class II MHC molecules for subsequent interaction with $\mathrm{CD} 4{ }^{+} \mathrm{T}$ cells ${ }^{95}$. Therefore, it is not surprising that the use of a protein-containing vaccine for fungi is thought to be strictly dependent on the presence of $\mathrm{CD}^{+} \mathrm{T}$ cells (FIG. 3). This postulate is supported by the finding that the protective efficacy of the H. capsulatum Hsp60 vaccine was abolished when $\mathrm{CD}^{+} \mathrm{T}$ cells, but not $\mathrm{CD} 8^{+} \mathrm{T}$ cells, were depleted before immunization ${ }^{87}$. The reliance on this cell population for protective immunity can be disadvantageous, especially if one seeks to vaccinate individuals with altered $\mathrm{CD}^{+}$ T-cell function, such as those receiving immunosuppressive agents or those with reduced $\mathrm{CD} 4^{+} \mathrm{T}$-cell numbers such as AIDS patients.

The T-cell-dependent response to $H$. capsulatum Hsp60 or the fragment of the protein that contains the protective domain (F3) is highly biased at the T-cell receptor (TCR) level ${ }^{96,97}$. Most T cells contain two heterodimeric chains, $\alpha$ and $\beta$, that confer the specificity for antigen recognition. The $\beta$ chain consists of variable $(\mathrm{V})$, diversity $(\mathrm{D})$, joining $(\mathrm{J})$ and constant $(\mathrm{C})$ regions, whereas the $\alpha$ chain contains only $\mathrm{V}$, J and $\mathrm{C}$ regions. The gene segments encoding these regions undergo somatic rearrangement to produce a functional TCR. In mice, there are $20 \mathrm{~V} \beta$ chains and $50-100 \mathrm{~V} \alpha$ chains. This provides $T$ cells with sufficient diversity to recognize the numerous antigens that the host encounters ${ }^{98}$.

Immunization with Hsp60 induces a dominant population of T cells that express a particular TCR, the $\mathrm{V} \beta$ 8.1/8.2 TCR. This population of T cells is required for protective immunity as its depletion eliminates the 
protective efficacy of Hsp60. Among this population, protection is confined to a small subpopulation that both releases IFN- $\gamma$ and reacts to the F3 fragment of Hsp60. Interestingly, vaccination with the $\mathrm{F} 3$ fragment induces $\mathrm{V} \beta 6^{+}$and not $\mathrm{V} \beta$ 8.1/8.2 $2^{+}$cells, with protection confined to $V \beta^{+} \mathrm{T}$ cells that secrete $\mathrm{T}_{\mathrm{H}} 1$ cytokines ${ }^{97}$. The reason or reasons for the expansion of two disparate $\mathrm{V} \beta$ T-cell populations will most likely be found at the level of antigen processing and presentation, as the immunogenic peptides generated by digestion of the F3 fragment and Hsp60 must be different. These findings raise concerns about vaccination in large populations. If the efficacy of a protein antigen is entirely dependent on a specific subset of $\mathrm{T}$ cells, it is possible that a certain proportion of the population that lacks the reactive $\mathrm{T}$ cells would fail to respond to vaccination.

Engaging $\mathrm{CD}^{+} \mathrm{T}$ cells is crucial for generating T-cell-dependent antibody formation, but the necessity for humoral immunity in vaccine efficacy remains unknown. In fact, all approved human vaccines rely on the induction of antibodies to mediate immunity. Therefore, the ability to induce humoral immunity could add to the effectiveness of a protein-containing vaccine. Studies in several pathogenic fungi have shown that antibodies against cell-surface molecules, whether complex carbohydrates or proteins, can be used in immunotherapy ${ }^{36,58,99}$. Many of these studies have shown that only specific B-cell clones can produce the proper antibody that is capable of transferring protective immunity. The challenge is inducing only antibody isotypes that are protective and not those isotypes that inhibit host defences or exert no positive effect on immunity.

An alternative approach to vaccination is to deliver T cells or APCs such as DCs. T cells from mice that have been immunized with protein antigens can vaccinate Aspergillus-infected mice ${ }^{83,100}$. The transfer of DCs loaded with the Ag2/PRA antigen induces protective immunity in an IFN- $\gamma$-dependent manner ${ }^{100}$. Likewise, antigen-loaded DCs confer protection in an animal model of human aspergillosis ${ }^{101}$.

Many proteins that are generated by pathogenic fungi are glycosylated, but most of the studies with recombinant proteins in the medical mycology field have used proteins generated in Escherichia coli. Although recombinant proteins produced by this bacterium lack glycosylation, they do mediate protective immunity ${ }^{87,88,93}$. This finding, however, does not imply that glycosylation is unimportant for immune protection by protein antigens. There are virtually no studies that compare the protective efficacy of glycosylated and non-glycosylated recombinant proteins. Mannosylation of the model antigen ovalbumin dramatically enhances its antigenicity, as assessed by T-cell proliferation ${ }^{102}$. If these findings can also be extended to the production of cytokines, it is quite likely that the addition of carbohydrate moieties to immunogenic protein antigens could enhance their potency or reduce the amount required to achieve protection ${ }^{102}$.

Another approach to potentially augment the potency of fungal vaccines is to create vaccines that contain more than one antigen. The use of such an approach would be to enhance the potency of a single antigen and engage a broader repertoire of T-cell families. The constituents of a multivalent vaccine should be at least additive, if not synergistic. Vaccination with a recombinant protein consisting of a fusion between the Ag2/ PRA antigen from C. immitis with the Coccidioidesspecific antigen from C. posadasii provided superior efficacy to vaccination with either recombinant protein alone, although surviving mice had a higher burden of infection $\left(10^{4}\right.$ colony-forming units) in the lungs ${ }^{103}$. Likewise, in experimental coccidioidomycosis, a trivalent vaccine consisting of recombinant phospholipase $B$, aspartyl proteinase and $\alpha$-mannosidase exhibited superior efficacy to each protein alone. The number of colony-forming units was markedly decreased in surviving mice ${ }^{104}$. Therefore, the data suggest that this approach is feasible and provides another approach to improve the efficacy of fungal vaccines.

\section{Stimulating multiple arms of immunity}

The foregoing discussion underscored the importance of stimulating $\mathrm{CD}^{+} \mathrm{T}$ cells and their soluble $\mathrm{T}_{\mathrm{H}} 1$ cytokines for the efficacy of vaccines containing purified protein antigens that mediate protective immunity to fungi (FIG. 3). CD4 ${ }^{+} \mathrm{T}$ cells have a central role in both primary and secondary immunity to disease caused by H. capsulatum ${ }^{105}$. This T-cell subset is also responsible for vaccine-induced resistance to $B$. dermatitidis disease in immunocompetent hosts ${ }^{106}$. These and other studies of fungal vaccines suggest that $\mathrm{CD}^{+} \mathrm{T}$ cells must be recruited for vaccine efficacy, even where antibodies participate in resistance. As indicated above, this recruitment should be feasible in healthy hosts who are given a purified protein vaccine, but perhaps might not be feasible in hosts in which $\mathrm{CD} 4^{+} \mathrm{T}$ cells are depleted in number or their function is altered.

Are there other ways to induce immunity that recruits additional $\mathrm{T}$-cell subsets, for example $\mathrm{CD}{ }^{+}$ $\mathrm{T}$ cells, and a broader profile of immunity than is feasible with purified protein vaccines? Perhaps other recombinant approaches, such as vaccination with nucleic acids or live attenuated fungi, might help fill this gap (FIG. 5). Genetic immunization involves the delivery of nucleic acid encoding a gene(s) of interest into a host by one of several methods; naked DNA injection into muscle and particle bombardment into the skin by a gene gun are the most common ${ }^{107}$. The early 1990s witnessed initial reports of naked DNA administration into muscle for gene expression in $v i v o^{108}$. These exciting studies are now moving towards the development of vaccines against infectious diseases and cancer. One advantage of genetic immunization is the ability to control the orientation and magnitude of the immune response to a gene product. This advantage stems partly from the fact that the gene products are expressed inside host cells, and therefore engage the endogenous pathway of antigen processing and presentation (FIG. 5). This pathway leads to the recruitment of $\mathrm{CD} 8^{+} \mathrm{T}$ cells ${ }^{107,109}$, which also mediate resistance to fungi (see below). Released or secreted antigens from transfected or dying cells can 
also facilitate antigen processing and presentation by the exogenous or class II MHC pathway, which preferentially stimulates $\mathrm{CD} 4^{+} \mathrm{T}$ cells. A DNA-encoded antigen can be targeted to additional locations, such as the cell membrane or the extracellular milieu, and can also be introduced with additional sequences encoding cytokines or adjuvants, such as immunostimulatory sequences. These features might be useful for vaccination against fungi, as broader immune responses including robust $\mathrm{CD} 8^{+} \mathrm{T}$ cell responses can be recruited by these methods.

Nucleic acid vaccination has been achieved in experimental models of invasive fungal disease due to C. immitis, P. brasiliensis, A. fumigatus and P. marneffe $i^{91,93,109-117}$. Most studies so far have examined C. immitis antigens, especially Ag2/PRA, the expression library immunization-antigen 1 (ELI-Ag1) and urease $\mathrm{e}^{3,118}$. DNA vaccines have generally been more effective than the respective recombinant-protein vaccines. Studies of DNA vaccination against fungi have pointed out the role of several variables in the efficacy of DNA vaccines, including the amount of DNA administered ${ }^{114}$, the route of DNA administration ${ }^{116}$, the value of IL-12 sequences as an adjuvant ${ }^{111}$ and even the inclusion of DNA encoding a signal sequence in the case of the Ag2/PRA DNA vaccine ${ }^{114}$. Studies in other disease models have also shown that larger quantities of DNA can be more immunogenic and that the location of DNA delivery - lung, epidermis or muscle - can influence the orientation of the $\mathrm{T}_{\mathrm{H}}$ cell response ${ }^{114}$. Early studies have been encouraging, but most C. immitis DNA vaccines have used a model of intra-peritoneal infection for initial screening. Whether this vaccine approach is useful against the natural pulmonary route of infection with $C$. immitis has yet to be tested. Presumably, these fungal DNA vaccines function by stimulating cellular immunity, particularly the response of $\mathrm{CD} 4^{+} \mathrm{T}$ cells and $\mathrm{T}_{\mathrm{H}} 1$ cytokines, but they also induce strong antibody responses ${ }^{91,112,114}$. Their mechanism of action and the contribution of antibody and $\mathrm{CD}^{+} \mathrm{T}$ cells has not been explored, and are significant areas of ongoing investigation. By contrast, recombinant Ag2/PRA given in conjunction with immunostimulatory oligodeoxynucleotides protects mice in a manner that requires IL-12, IFN- $\gamma$ and MHC class II restricted $\mathrm{T}$ cells, whereas $\mathrm{CD} 8^{+} \mathrm{T}$ cells are not required ${ }^{94}$. Because human clinical trials of DNA vaccines have reported low immunogenicity, regimens to increase vaccine potency, such as a DNA prime and protein boost regime, are under investigation ${ }^{119}$.

DCs are among the most potent APCs for stimulating immune responses, prompting investigators to harness these cells for the delivery and presentation of fungal antigens, including nucleic acid. DCs transfected with nucleic acid from C. albicans or A. fumigatus were able to induce resistance against experimental disease with the respective pathogens ${ }^{117}$. In another study, a DC line was transfected with C. immitis PRA and introduction of these cells into the lungs of mice produced a $T_{H} 1$ cytokine response and resistance against experimental disease with this fungus ${ }^{100}$.

\section{Live attenuated fungi as vaccines}

In the field of vaccinology, there are several examples of highly efficacious infectious-disease vaccines derived from live attenuated infectious agents, principally viruses, including polio, measles, mumps, rubella, varicella, influenza and, most recently, rotavirus ${ }^{120}$. The advantages of using a live agent are that the pathogen replicates at the site of infection and induces strong, broad responses involving multiple arms of the immune response (FIC. 5), which recapitulates natural immunity to disease. By contrast, protein or killed agents might not access the endogenous antigen-processing pathway and induce $\mathrm{CD}^{+}$ T-cell responses. Such immune responses contribute to protective immunity against many pathogenic fungi, including $H$. capsulatum, $B$. dermatitidis, $P$. brasiliensis, C. neoformans, Pneumocystis carinii and perhaps others as well ${ }^{85,121-125}$.

Work on B. dermatitidis has demonstrated the efficacy of live attenuated fungi for vaccination, and the benefit of using live organisms to recruit multiple arms of the host immune response. It had been postulated that stimulating an immune response to a major virulence factor, such as Blastomyces adhesin 1 (BAD1) from $B$. dermatitidis, could provide the host with a selective advantage and protect against disease, either through prompt pathogen recognition or possibly by neutralization of virulence factor function. However, when recombinant $\mathrm{BAD} 1$ was used to vaccinate mice ${ }^{88,126}$ the vaccine efficacy was not striking, even when combined with IL-12 as an adjuvant ${ }^{126}$.

The inability of BAD1 to rescue mice from a lethal pulmonary challenge with $B$. dermatitidis prompted other approaches to vaccination against blastomycosis. A genetically engineered $B A D 1$ null mutant is sharply attenuated in a mouse model ${ }^{127}$. This finding suggested that it might induce an immune response in mice and so vaccine protection. When live yeast of the BAD1 null mutant were injected subcutaneously in the absence of adjuvant, most of the vaccinated mice survived a lethal challenge and evidence of sterilizing immunity was obtained ${ }^{128}$. This report established that a genetically engineered fungus strain could be used as a vaccine. Experimental vaccine studies had previously been carried out with natural fungal variants that exhibited loss of pathogenicity; that is, a strain of C. albicans that had lost its ability to filament and a temperature-sensitive variant of $C$. immitis that grew poorly at $37^{\circ} \mathrm{C}$ (REFS 129,130). A concern with natural variants, however, is the potential for reversion to virulence.

Studies of the protective mechanisms of the live attenuated $B$. dermatitidis vaccine uncovered plasticity in the residual immune elements in compromised hosts at both the molecular and cellular level ${ }^{106}$ (FIG. 3). In immunocompetent mice, $\mathrm{CD} 4{ }^{+} \mathrm{T}$ cells mediated resistance mainly by the production of TNF- $\alpha$ and IFN- $\gamma^{106}$. Although both of these cytokines are crucial mediators of the expression or efferent phase of vaccine immunity, the efficacy of vaccination with the mutant strain did not require the pre-existing presence of IFN- $\gamma$ or TNF- $\alpha$. The efficacy of vaccination in IFN- $\gamma^{/-}$or TNF- $\alpha^{-1-}$ mice required either the reciprocal cytokine or granulocytemacrophage colony-stimulating factor (GM-CSF). 


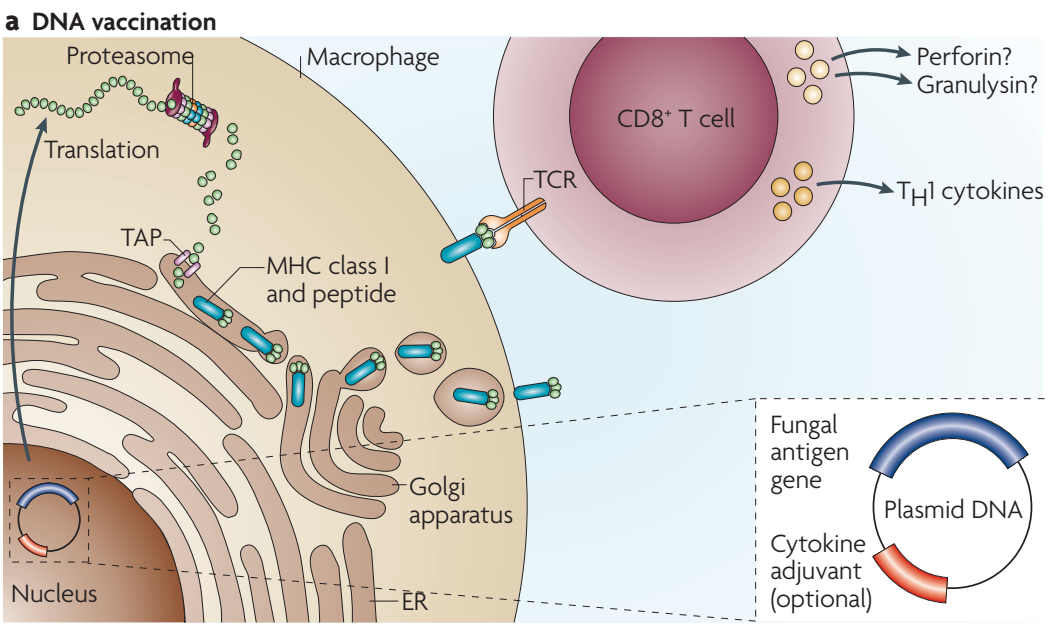

b Protein antigen vaccination
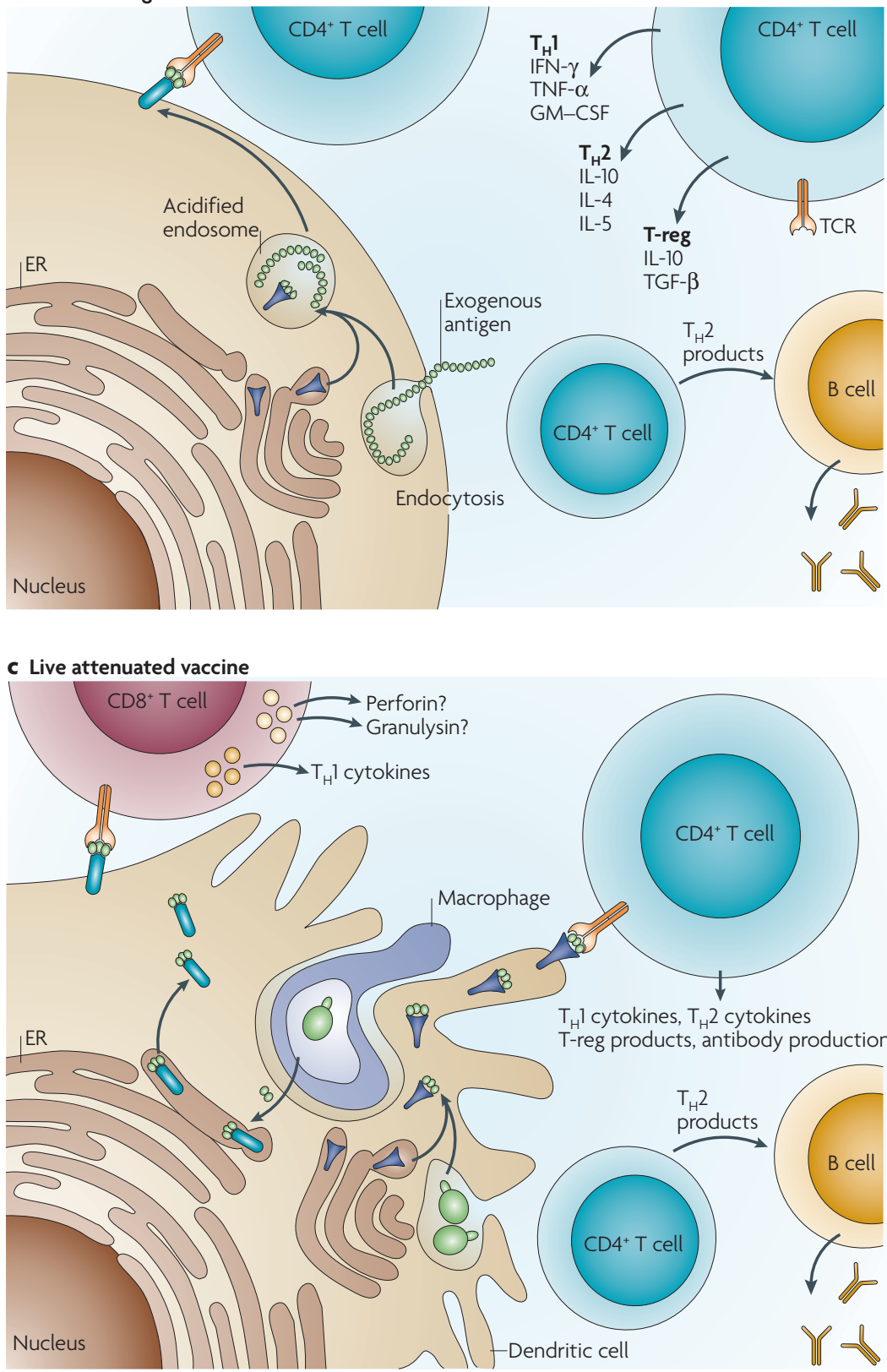

Figure 5 | The profiles of the anti-fungal immune responses induced by various immunogens. a | In DNA vaccination, the plasmid DNA contains a fungal gene that is often under the control of an active promoter. Other genes can be co-expressed, for example cytokines such as interleukin (IL)-12 that can exert adjuvant effects. The fungal proteins are translated and from the cytosol enter the endogenous route of antigen processing, as shown in Fig. 4a. Therefore, this vaccine strategy primes $C D 8+T$ cells, which function by producing T-helper $1\left(\mathrm{~T}_{H} 1\right)$ cytokines, and perhaps lytic products such as perforin or granulysin. A secretion signal (not shown) can be engineered onto the antigen sequence so that the expressed gene product is exported out of the cell, and thereby enters the exogenous antigen-processing pathway, as shown in Fig. 4b, priming CD4 ${ }^{+} T$ cells and their soluble products. $\mathbf{b}$ | In vaccination with a protein antigen, the soluble protein and an adjuvant enter the exogenous antigen-processing pathway, which chiefly primes $\mathrm{CD}^{+} \mathrm{T}$ cells. These cells perform helper and regulatory functions by releasing various soluble products, which arm phagocytes, balance the unrestrained vigor of the immune response, and help $B$ cells produce antibody. $\mathbf{c} \mid A$ live attenuated vaccine can enter antigen-presenting cells, especially dendritic cells, by multiple routes. The vaccine primes $C D 4^{+} T$ cells through the exogenous antigen-processing pathway pathway and $C D 8^{+} T$ cells through cross presentation. This engages multiple arms of the immune response, including multiple T-cell subsets and their accompanying products, and B cells and antibody production. GM-CSF, granulocyte-macrophage colony-stimulating factor; IFN, interferon; MHC, major histocompatibility complex; TCR, T-cell receptor; TGF, transforming growth factor; TNF, tumour necrosis factor; T-reg, regulatory T cell.

The vaccine required the presence of TCR $\alpha \beta^{+}$cells but functioned unexpectedly well in the absence of either $\mathrm{CD}^{+}$or $\mathrm{CD}^{+} \mathrm{T}$ cells. This study demonstrated that vaccination of immunodeficient hosts can be accomplished. This finding has implications for developing vaccines for use in hosts that are vulnerable to fungal disease owing to the loss of immune function.

These studies were extended to $H$. capsulatum and to additional immunodeficient hosts, and it was found that the efficacy of the live attenuated vaccine in $\mathrm{CD}^{-/-}$mice relies on the presence of competent $\mathrm{CD} 8^{+}$ $\mathrm{T}$ cells ${ }^{85}$. The $\mathrm{CD} 8^{+} \mathrm{T}$ cells interact with MHC class I antigens. Therefore, antigens from the live attenuated yeast were either accessing the endogenous pathway of antigen processing, or were being cross-presented and cross-priming $\mathrm{CD} 8^{+} \mathrm{T}$ cells (FIG. 5). $\mathrm{CD} 8^{+} \mathrm{T}$ cells can function appropriately in the absence of either TNF- $\alpha$ or IFN- $\gamma$. In the absence of TNF- $\alpha$, GM-CSF compensates and in the absence of IFN- $\gamma$, TNF- $\alpha$ and GM-CSF regulate the expression of immunity. Vaccine-mediated immunity to $B$. dermatitidis and $H$. capsulatum thereby overcame a requirement for $\mathrm{CD} 4^{+} \mathrm{T}$-cell help, and this immunity was durable in mice for at least 8 weeks postvaccination. This is in contrast to the findings of recent studies on $\mathrm{CD} 4^{+} \mathrm{T}$-cell-independent $\mathrm{CD} 8^{+}$memory 
T-cell responses against viral and bacterial diseases ${ }^{131,132}$, which waned over a similar interval of time, indicating that $\mathrm{CD}^{+} \mathrm{T}$-cell memory to fungi might be longer lasting and biologically distinct from $\mathrm{CD}^{+} \mathrm{T}$-cell memory against viruses and bacteria.

These studies show the efficacy of using live attenuated fungi for vaccination, the ability of these immunogens to recruit multiple arms of the immune response, including both $\mathrm{CD}^{+}$and $\mathrm{CD} 8^{+} \mathrm{T}$ cells, and the unexpected finding that immunodeficient hosts can control a live attenuated vaccine and compensate for the loss of elements of the immune response by substituting other elements to confer protective immunity.

There are other examples of live attenuated vaccines against fungi. A targeted mutant of $C$. immitis in which two chitinase genes were deleted is unable to convert from an infectious arthroconidial form into an endosporulating, pathogenic spherule form, and is avirulent after intranasal injection in mice (G. Cole, personal communication). This strain elicits immunity and resistance in subcutaneously vaccinated mice against a lethal pulmonary disease with wild-type arthroconidia of C. immitis. These findings support the observations above with $B$. dermatitidis and $H$. capsulatum, and extend the results to a novel type of genetically engineered mutant, which is impaired in morphogenesis to a virulent form. The fungus is physically unable to mature into a virulent state, which might increase its safety. Another live attenuated fungal vaccine has been developed for prevention of ringworm caused by Trichophyton verrucosum in cattle ${ }^{133}$. The attenuated strain has been tested in controlled challenge-exposure experiments and in field trials. In studies of $>400,000$ vaccinated cattle over a 5-year period, it was concluded that trichophytosis in cattle can be controlled by immunoprophylaxis with negligible side effects.

We emphasize that there are theoretical and real concerns in using live pathogens for vaccination. Even if 'unnatural immunity' can be recruited to confer vaccine efficacy in immunocompromised hosts ${ }^{134}$, a formidable issue is whether vulnerable patients can contain even an attenuated live pathogen. Live non-pathogenic fungi have been explored as vaccine vehicles for the delivery of immunogens, including heterologous antigens. This concept was tested in Saccharomyces cerevisiae ${ }^{135}$. This yeast, when genetically engineered to express the model antigen ovalbumin, could access DCs and prime $\mathrm{CD} 4^{+}$ $\mathrm{T}$ cells in addition to cross priming $\mathrm{CD}^{+} \mathrm{T}$ cells. As well as priming multiple arms of immunity, this strategy adds the potent adjuvant properties of the yeast $\beta$-glucan and, because of the genetic tractability of this yeast, it also offers the ability to deliver multiple vaccine antigens in a single immunogenic vehicle.

\section{Perspectives}

The level of our understanding of fungal-host interactions has progressed to the point where vaccines against both primary fungal pathogens and the prevalent opportunistic fungi are becoming a reality. Prototypic antigens, both subcellular and whole cells, have been identified, against which protective immunity can be induced. The mechanisms of immunity vary from antibody-mediated immune responses to cell-mediated responses, and even a combination of both of these main arms of the acquired immune system. As we move closer to the reality of human clinical vaccine trials, a range of theoretical questions regarding the safety and efficacy of fungal vaccines have been raised. These questions include whether such vaccines are necessary ${ }^{1,3-5}$, whether they can be made efficacious in immunodeficient hosts ${ }^{1,2,85}$, whether, as in the case of vaccines against $C$. albicans, they can prevent disseminated disease without affecting C. albicans as a member of the normal microbiota ${ }^{1,136}$, and whether fungal vaccines against agents commonly encountered by humans will result in, or possibly prevent, allergic manifestations ${ }^{1,136-139}$. Answers to these questions will not be known until human vaccine trials are initiated. So far, a killed spherule vaccine against coccidioidomycosis is the only human fungal vaccine field trial ever conducted $^{140}$. The negative protection results obtained were more likely caused by the inability to use immunogenic doses of the vaccine because of toxic manifestations of the appropriate dose, than to the vaccine being unable to induce protection ${ }^{140,141}$. In spite of the theoretical questions posed above, the results of preliminary vaccine studies on the prevention of coccidioidomycosis should encourage, rather than stifle, enthusiasm to pursue vaccine development against the ever-growing problem posed by fungal diseases. Although mouse models of human mycoses have served us well in defining candidate antigens and vaccine formulations, it is time to move towards clinical trials in humans.

Is a universal vaccine against mycotic disease possible? The experiments involving protective antibody responses against $\beta$-1,3-glucan that have been carried out so far are limited in scope, but suggest that a universal fungal vaccine could be developed. The fact that $\beta$-glucans are found in many fungal pathogens (see above), along with the immunomodulation activities of this polysaccharide ${ }^{142}$, implies that $\beta$-glucan would be an important vaccine component. The inclusion of other oligosaccharides, such as the GXM heptasaccharide epitope and C. albicans $\beta$-linked mannotriose, could improve the vaccine effectiveness. Additional epitopes that should be considered are GXM peptide mimotopes and the LKVIRK epitope of the C. albicans Hsp90 antigen ${ }^{143,144}$. Prudent choice of the protein carrier for the carbohydrate epitopes could further broaden the spectrum of coverage by using fungal proteins that fulfil the carrier function and induce protective $T_{H} 1$ dependent responses or additional protective antibody responses. For example, the two or three carbohydrate moieties could be coupled to a mixture of Hsp60 from H. capsulatum, BAD1 from B. dermatitidis, Ag2/PRA protein from $C$. immitis and, perhaps, the protein from C. albicans that led to the isolation of the C7 monoclonal antibody ${ }^{44,80}$. Of course a myriad of questions would need to be addressed before such a vaccine was developed, but the ever increasing problems with fungal diseases and the level of our understanding of fungalhost interactions now make this a prospect worthy of consideration. 
1. Mochon, A. B. \& Cutler, J. E. Is a vaccine needed against Candida albicans? Med. Mycol. 43, 97-115 (2005).

2. Deepe, G. S. Jr, Wüthrich, M. \& Klein, B. S. Progress in vaccination for histoplasmosis and blastomycosis: coping with cellular immunity. Med. Mycol. 43, 381-389 (2005)

3. Cole, G. T. et al. A vaccine against coccidioidomycosis is justified and attainable. Med. Mycol. 42, 189-216 (2004).

This work is an outstanding contemporary review of the topic.

4. Deepe, G. S. Jr. Preventative and therapeutic vaccines for fungal infections: from concept to implementation. Expert Rev. Vaccines 3, 1-9 (2004).

5. Casadevall, A. \& Pirofski, L.-A. Feasibility and prospects for a vaccine to prevent cryptococcosis. Med. Mycol. 43, 667-680 (2005).

6. Feldmesser, M. Prospects of vaccines for invasive aspergillosis. Med. Mycol. 43, 571-587 (2005).

7. Newman, S. L., Bucher, C., Rhodes, J. \& Bullock, W. E. Phagocytosis of Histoplasma capsulatum yeasts and microconidia by human cultured macrophages and alveolar macrophages: cellular cytoskeleton requirement for attachment and ingestion. J. Clin. Invest. 85, 223-230 (1990).

8. Klein, B. S. \& Newman, S. L. Role of cell-surface molecules of Blastomyces dermatitidis in host-pathogen interactions. Trends Microbiol. 4, 246-251 (1996)

9. Mansour, M. K., Schlesinger, L. S. \& Levitz, S. M Optimal T cell responses to Cryptococcus neoformans mannoprotein are dependent on recognition of conjugated carbohydrates by mannose receptors. J. Immunol. 168, 2872-2879 (2002).

10. Taborda, C. P. \& Casadevall, A. CR3 (CD1b/CD18) and CR4 (CD 11 c/CD18) are involved in complementindependent antibody-mediated phagocytosis of Cryptococcus neoformans. Immunity 16, 791-802 (2002).

11. Netea, M. G. et al. Toll-like receptor 2 suppresses immunity against Candida albicans through induction of IL-10 and regulatory T cells. J. Immunol. 172 3712-3718 (2004).

12. Hohl, T. M. et al. Aspergillus fumigatus triggers inflammatory responses by stage-specific $\beta$-glucan display. PLoS Pathog. 1, e30 (2005).

13 Gersuk, G. M., Underhill, D. M., Zhu, L. \& Marr, K. A Dectin- 1 and TLRs permit macrophages to distinguish between different Aspergillus fumigatus cellular states. J. Immunol. 176, 3717-3724 (2006).

14. Marth, T. \& Kelsall, B. L. Regulation of interleukin-12 by complement receptor 3 signaling. J. Exp. Med. 185, 1987-1995 (1997)

15. Romani, L. et al. Neutrophil production of IL-12 and IL-10 in candidiasis and efficacy of IL-12 therapy in neutropenic mice. J. Immunol. 158, 5349-5356 (1997).

16. Bacci, A. et al. Dendritic cells pulsed with fungal RNA induce protective immunity to Candida albicans in hematopoietic transplantation. J. Immunol. 168 2904-2913 (2002).

17. Rolston, K. V. Management of infections in the neutropenic patient. Annu. Rev. Med. 55, 519-526 (2004).

18. Mencacci, A. et al. CD80+ $\mathrm{Gr}-1^{+}$myeloid cells inhibit development of antifungal $T_{H} 1$ immunity in mice with candidiasis. J. Immunol. 169, 3180-3190 (2002).

19 Mednick, A. J., Feldmesser, M., Rivera, J \& Casadevall, A. Neutropenia alters lung cytokine production in mice and reduces their susceptibility to pulmonary cryptococcosis. Eur. J. Immunol. 33, 1744-1753 (2003).

20. Gildea, L. A., Morris, R. E. \& Newman, S. L. Histoplasma capsulatum yeasts are phagocytosed via very late antigen-5, killed, and processed for antigen presentation by human dendritic cells. J. Immunol. 166, 1049-1056 (2001).

21. Romani, L., Bistoni, F. \& Puccetti, P. Fungi, dendritic cells and receptors: a host perspective of fungal virulence. Trends Microbiol. 10, 508-514 (2002).

22. Gildea, L. A., Ciraolo, G. M., Morris, R. E. \& Newman, S. L. Human dendritic cell activity against Histoplasma capsulatum is mediated via phagolysosomal fusion. Infect. Immun. 73, 6803-6811 (2005).

23. Garlanda, C. et al. Non-redundant role of the long pentraxin PTX3 in anti-fungal innate immune response. Nature 420, 186 (2002).
24. McCormack, F. X. et al. Macrophage-independent fungicidal action of the pulmonary collectins. J. Biol. Chem. 278, 36250-36256 (2003).

25. Huffnagle, G. B. \& Deepe, G. S. Jr. Innate and adaptive determinants of host susceptibility to medically important fungi. Curr. Opin. Microbiol. 6, 344-350 (2003)

26. Romani, L. Immunity to fungal infections. Nature Rev. Immunol. 4, 1-13 (2004).

27. Lijin, L., Dial, S. M., Rennels, M. A. \& Ampel, N. M. Cellular immune suppressor activity resides in lymphocyte cell clusters adjacent to granulomata in human coccidiodomycosis. Infect. Immun. 73, 3923-3928 (2005)

28. Pilar-Jimenez, M., Walls, L. \& Fierer, J. High levels of interleukin-10 impair resistance to pulmonary coccidioidomycosis in mice in part through control of nitric oxide synthase 2 expression. Infect. Immun. $\mathbf{7 4 ,}$ 3387-3395 (2006).

29. Goldman, D. L. et al. Serologic evidence for Cryptococcus neoformans infection in early childhood. Pediatrics 107, E66 (2001)

30. Mourad, S. \& Friedman, L. Passive immunization of mice against Candida albicans. Sabouraudia 6 , 103-105 (1968).

31. Pearsall, N. N., Adams, B. L. \& Bunni, R. Immunologic responses to Candida albicans. III. Effects of passive transfer of lymphoid cells or serum on murine candidiasis. J. Immunol. 120, 1176-1180 (1978).

32. Casadevall, A. Antibody immunity and invasive fungal infections. Infect. Immun. 63, 4211-4218 (1995).

33. Cutler, J. E. Defining criteria for anti-mannan antibodies to protect against candidiasis. Curr. Mol. Med. 5, 383-392 (2005).

34. Taborda, C. P., Rivera, J., Zaragoza, O. \& Casadevall, A More is not necessarily better: prozone-like effects in passive immunization with IgG. J. Immunol. 170 , 3621-3631 (2003)

35. Feldmesser, M., Kress, Y., Novikoff, P. \& Casadevall, A. Cryptococcus neoformans is a facultative intracellular pathogen in murine pulmonary infection. Infect. Immun. 68, 4225-4238 (2000)

36. Nosanchuk, J. D., Steenbergen, J. N., Shi, L., Deepe, G. S. Jr \& Casadevall, A. Antibodies to a cell surface histone-like protein protect against Histoplasma capsulatum. J. Clin. Invest. 112, 1164-1175 (2003). This article demonstrates that immunotherapy with antibodies can protect against an intracellular fungal pathogen.

37. Casadevall, A. Antibody-mediated immunity against intracellular pathogens: two-dimensional thinking comes full circle. Infect. Immun. 71, 4225-4228 (2003).

38. Nosanchuk, J. D. Protective antibodies and endemic dimorphic fungi. Curr. Mol. Med. 5, 435-442 (2005).

39. Casadevall, A. \& Pirofski, L. Insights into mechanisms of antibody-mediated immunity from studies with Cryptococcus neoformans. Curr. Mol. Med. 5 421-433 (2005).

40. Torosantucci, A. et al. A novel glyco-conjugate vaccine against fungal pathogens. J. Exp. Med. 202. 597-606 (2005) This work on protection by anti- $\beta$-glucan antibodies provides a basis for the development of a fungal vaccine that is broadly active against various fungal agents.

41. Grappel, S. F. \& Calderone, R. A. Effect of antibodies on the respiration and morphology of Candida albicans. S. Afr. Med. J. 14, 51-60 (1976).

42. Casanova, M., Martinez, J. P. \& Chaffin, W. L. Fab fragments from a monoclonal antibody against a germ tube mannoprotein block the yeast-to-mycelium transition in Candida albicans. Infect. Immun. $\mathbf{5 8}$ 3810-3812 (1990)

43. Magliani, W. et al. Therapeutic potentials of antiidiotypic single chain antibodies with yeast killer toxin activity. Nature Biotech. 15, 155-158 (1997)

44. Moragues, M. D. et al. A monoclonal antibody directed against a Candida albicans cell wall mannoprotein exerts three anti-C. albicans activities. Infect. Immun. 71, 5273-5279 (2003).

45. Pirofski, L. A. \& Casadevall, A. Use of licensed vaccines for active immunization of the immunocompromised host. Clin. Microbiol. Rev. 11, 1-26 (1998).

46. Han, Y. et al. Complement is essential for protection by an IgM and an IgC3 monoclonal antibody against experimental hematogenously disseminated candidiasis. J. Immunol. 167, 1550-1557 (2001). This paper shows that protection against candidiasis by anti-mannan antibodies is dependent on complement factor 3 .
47. Xin, H. \& Cutler, J. E. Hybridoma passage in vitro may result in reduced ability of antimannan antibody to protect against disseminated candidiasis. Infect. Immun. 74, 4310-4321 (2006).

48. Devi, S. J. Preclinical efficacy of a glucuronoxylomannan-tetanus toxoid conjugate vaccine of Cryptococcus neoformans in a murine model. Vaccine 14, 841-844 (1996). Erratum in: Vaccine 14, 1298 (1996).

49. Casadevall, A. et al. Antibodies elicited by a Cryptococcus neoformans-tetanus toxoid conjugate vaccine have the same specificity as those elicited in infection. J. Infect. Dis. 165, 1086-1093 (1992).

50. Casadevall, A. et al. Characterization of a murine monoclonal antibody to Cryptococcus neoformans polysaccharide that is a candidate for human therapeutic studies. Antimicrob. Agents Chemother 42, 1437-1446 (1998)

51. Ellerbroek, P. M., Walenkamp, A. M. E., Hoepelman, A. I. M. \& Coenjaerts, F. E. J. Effects of the capsular polysaccharides of Cryptococcus neoformans on phagocyte migration and inflammatory mediators. Curr. Med. Chem. 11, 253-266 (2004)

52. Vecchiarelli, A. Immunoregulation by capsular components of Cryptococcus neoformans. Med. Mycol. 38, 407-417 (2000)

53. Oscarson, S., Alpe, M., Svahnberg, P., Nakouzi, A. \& Casadevall, A. Synthesis and immunological studies of glycoconjugates of Cryptococcus neoformans capsular glucuronoxylomannan oligosaccharide structures. Vaccine 23, 3961-3972 (2005)

54. Maittra, R. W., Datta, K., Lees, A., Belouski, S. S. \& Pirofski, L.-A. Immunogenicity and efficacy of Cryptococcus neoformans capsular polysaccharide glucuronoxylomannan peptide mimotope-protein conjugates in human immunoglobulin transgenic mice. Infect. Immun. 72, 196-208 (2004).

55. Abadi, J. \& Pirofski, L. A. Antibodies reactive with the cryptococcal capsular polysaccharide glucuronoxylomannan are present in sera from children with and without human immunodeficiency virus infection. J. Infect. Dis. 180, 915-919 (1999).

56. Shibata, N. et al. Existence of branched side chains in the cell wall mannan of pathogenic yeast, Candida albicans. J. Biol. Chem. 270, 1113-1122 (1995). This hallmark publication is a culmination of work that has taught us about the chemistry of the cellsurface phosphomannan complexes of Candida albicans.

57. Poulain, D., Slomianny, C., Jouault, T., Gomez, J. M. \& Trinel, P. A. Contribution of phospholipomannan to the surface expression of $\beta$-1,2-oligomannosides in Candida albicans and its presence in cell wall extracts. Infect. Immun. 70, 4323-4328 (2002).

58. Han, Y. \& Cutler, J. E. Antibody response that protects against disseminated candidiasis. Infect. Immun. 63 , 2714-2719 (1995)

59. Han, Y., Ulrich, M. A. \& Cutler, J. E. Candida albicans mannan extract-protein conjugates induce a protective immune response against experimental candidiasis. J. Infect. Dis. 179, 1477-1484 (1999).

60. Nitz, M., Ling, C.-C., Otter, A., Cutler, J. E. \& Bundle, D. R. The unique solution structure and immunochemistry of the Candida albicans $\beta-1,2$ mannopyranan cell wall antigens. J. Biol. Chem. 277 , 3440-3446 (2002)

This paper shows that specificity of protective antibodies for $\beta$-linked oligomannosides is, surprisingly, inversely related to mannan chain length.

61. Goins, T. \& Cutler, J. E. Relative abundance of oligosaccharides in Candida species as determined by fluorophore-assisted carbohydrate electrophoresis. J. Clin. Microbiol, 38, 2862-2869 (2000).

62. Kobayashi, H. et al. Structures of cell wall mannans of pathogenic Candida tropicalis IFO 0199 and IFO 1647 yeast strains. Infect. Immun. 62, 615-622 (1994).

63. Shibata, N., Kobayashi, H., Okawa, Y. \& Suzuki, S. Existence of novel $\beta-1,2$ linkage-containing side chain in the mannan of Candida lusitaniae, antigenically related to Candida albicans. Eur. J. Biochem. 270, 2565-2575 (2003).

64. Nitz, M. Purse, B. W. \& Bundle, D. R. Synthesis of $\beta 1,2$ mannopyranosyl tetrasaccharide found in the phosphomannan antigen of Candida albicans. Org. Lett. 2, 2939-2942 (2000)

65. Wu, X. \& Bundle, D. R. Synthesis of glycoconjugate vaccines for Candida albicans using novel linker methodology. J. Org. Chem. 70, 7381-7388 (2005). 
66. Lipinski, T. et al. A synthetic glycoconjugate Candida albicans vaccine confers protection in a disseminated candidiasis rabbit model (A214). Proc. ASM Conf. Candida and Candidiasis [online], http://www.asm.org/ ASM/files/ccLibraryFiles/Filename/000000002193/ Candida\%20Program.pdf (2006)

67. Han, Y. \& Cutler, J. E. Assessment of a mouse model of neutropenia and the effect of an anti-candidiasis monoclonal antibody in these animals. J. Infect. Dis. 175, 1169-1175 (1997).

68. Han, Y., Morrison, R. P. \& Cutler, J. E. A vaccine and monoclonal antibodies that enhance mouse resistance to Candida albicans vaginal infection. Infect. Immun. 66, 5771-5776 (1998)

69. Casadevall, A. \& Pirofski, L. A. Polysaccharidecontaining conjugate vaccines for fungal diseases. Trends Mol. Med. 12, 6-9 (2006).

70. Johnson, S. Antibody responses to clostridial infection in humans. Clin. Infect. Dis. 25, S173-S177 (1997).

71. Maddaloni, M. et al. Immunological characteristics associated with the protective efficacy of antibodies to ricin. J. Immunol. 172, 6221-6228 (2004).

72. Hangartner, L., Zinkernagel, R. M. \& Hengartner, H. Antiviral antibody responses: the two extremes of a wide spectrum. Nature Rev. Immunol. 6, 231-243 (2006).

73. Lee, C.-J., Lee, L. H. \& Frasch, C. E. Protective immunity of pneumococcal glycoconjugates. Crit. Rev. Microbiol. 29, 333-349 (2003)

74. Saeland, E. et al. Central role of complement in passive protection by human $\operatorname{lgG} 1$ and $\lg 22$ antipneumococcal antibodies in mice. J. Immunol. 170 6158-6164 (2003)

75. Winkelstein, J. A. \& Moxon, E. R. The role of complement in the host's defense against Haemophilus influenzae. J. Infect. Dis. 165, S62-S65 (1992).

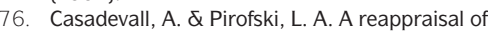
humoral immunity based on mechanisms of antibody mediated protection against intracellular pathogens. Adv. Immunol. 91, 1-44 (2006)

77. Small, J. M. \& Mitchell, T. G. Strain variation in antiphagocytic activity of capsular polysaccharides from Cryptococcus neoformans serotype A. Infect. Immun. 57, 3751-3756 (1989)

78. Mukherjee, J., Nussbaum, G., Scharff, M. D. \& Casadevall, A. Protective and nonprotective monoclonal antibodies to Cryptococcus neoformans originating from one B cell. J. Exp. Med. 181, 405-409 (1995)

This paper convincingly shows that antibodymediated protection against cryptococcosis is effected most by the non-complement fixing antibody IgG1 specific for capsular glucuronoxylomannan.

79. Dromer, F., Charreire, J., Contrepols, A., Carbon, C. \& Yeni, P. Protection of mice against experimental cryptococcosis by anti-Cryptococcus neoformans monoclonal antibody. Infect. Immun. 55, 749-752 (1987).

80. Sevilla, M. J., Robledo, B., Rementeria, A., Moragues, M. D. \& Ponton, J. A fungicidal monoclonal antibody protects against murine invasive candidiasis. Infect. Immun. 74, 3042-3045 (2006).

81. Allendoerfer, R. \& Deepe, G. S. Intrapulmonary response to Histoplasma capsulatum in $\gamma$ interferon knockout mice. Infect. Immun. 65, 2564-2569 (1997).

82. Romani, L. et al. Th1 and Th2 cytokine secretion patterns in murine candidiasis: association of Th 1 responses with acquired resistance. Infect. Immun. $\mathbf{5 9}$ 4647-4654 (1991).

83. Cenci, E. et al. T-cell vaccination in mice with invasive pulmonary aspergillosis. J. Immunol. 165, 381-388 (2000).

84. Magee, D. M. \& Cox, R. A. Interleukin-12 regulation of host defenses against Coccidioides immitis. Infect. Immun. 64, 3609-3613 (1996)

85. Wüthrich, M., Filutowicz, H. I., Warner, T., Deepe, G. S. \& Klein, B. S. Vaccine immunity to pathogenic fungi overcomes the requirement for $\mathrm{CD}_{4}{ }^{+}$help in exogenous antigen presentation to $\mathrm{CD}^{+}+\mathrm{T}$ cells implications for vaccine development in immunedeficient hosts. J. Exp. Med. 197, 1405-1416 (2003). This paper establishes that CD4 ${ }^{+}$T-cell-deficient hosts can be vaccinated against pathogenic fung by the recruitment of $\mathrm{CD}^{+} \mathrm{T}$ cells that mediate helper functions and immunity.
86. Huffnagle, G. B., Lipscomb, M. F., Lovchik, J. A., Hoag, K. A. \& Street, N. E. The role of $\mathrm{CD}^{+}$and CD8 $\mathrm{T}$ cells in the protective inflammatory response to a pulmonary cryptococcal infection. J. Leukoc. Biol. 55, 35-42 (1994).

87. Deepe, G. S. Jr \& Gibbons, R. S. Cellular and molecular regulation of vaccination with heat shock protein 60 from Histoplasma capsulatum. Infect. Immun. 70, 3759-3767 (2002).

88. Wüthrich, M., Chang, W.-L. \& Klein, B. S Immunogenicity and protective efficacy of the Wl-1 adhesin of Blastomyces dermatitidis. Infect. Immun 66, 5443-5449 (1998)

89. Bozza, S et al Vaccination of mice against invasive aspergillosis with recombinant Aspergillus proteins and $\mathrm{CpG}$ oligodeoxynucleotides as adjuvants. Microbes Infect. 4, 1281-1290 (2002).

90. Biondo, C. et al. Induction of T helper type 1 responses by a polysaccharide deacetylase from Cryptococcus neoformans. Infect. Immun. 71 5412-5417 (2003)

91. Abuodeh, R. O. et al. Resistance to Coccidioides immitis in mice after immunization with recombinant protein or a DNA vaccine of a proline-rich antigen. Infect. Immun. 67, 2935-2940 (1999).

92. Taborda, C. P. et al. Synthesis and immunological activity of a branched peptide carrying the T-cell epitope of gp43, the major exocellular antigen of Paracoccidioides brasiliensis. Scand. J. Immunol. 59 58-65 (2004).

93. Li, K., Yu, J.-J., Hung, C.-Y., Lehmann, P. F. \& Cole, G. T. Recombinant urease and urease DNA of Coccidioides immitis elicit an immunoprotective response against coccidioidomycosis in mice. Infect. Immun. 69 2878-2887 (2001)

94. Kirkland, T. N., Raz, E. \& Datta, S. K. Molecular and cellular mechanisms of protective immunity to coccidioidomycosis. Vaccine 24, 495-500 (2006).

95 Nelson, C. A., Harding C. V. \& Unanue, E. R. Biochemical anatomy of antigen processing. Cold Spring Harbor Symp. Quant. Biol. 57, 557-563 (1992).

96. Deepe, G. S. \& Gibbons, R. V $\beta 6^{+}$cells are obligatory for vaccine-induced immunity to Histoplasma capsulatum. J. Immunol. 167, 2219-2226 (2001)

97. Scheckelhoff, M. \& Deepe, G. S. Jr. The protective immune response to heat shock protein 60 of Histoplasma capsulatum is mediated by a subset of VB8.1/8.2+ T cells. J. Immunol. 169, 5818-5826 (2002).

This paper demonstrates the necessity for a small population of cells to mediate vaccine-induced immunity.

98. Chien, Y., Gascoigne, N. J. R., Kavaler, J., Lee, N. E. \& Davis, M. M. Somatic recombination in the murine T-cell receptor gene. Nature 312, 31-35 (1984)

99. Feldmesser, M., Mednick, A. ¿ Casadevall, A. Antibody-mediated protection in murine Cryptococcus neoformans infection is associated with pleotrophic effects on cytokine and leukocyte responses. Infect Immun. 70, 1571-1580 (2002).

100. Awasthi, S., Awasthi, V., Magee, D. M. \& Coalsen, J. J. Efficacy of antigen 2/proline-rich antigen cDNAtransfected dendritic cells in immunization of mice against Coccidioides posadasii. J. Immunol. 175 , 3900-3906 (2005)

101. Bozza, S. et al. A dendritic cell vaccine against invasive aspergillosis in allogeneic hematopoietic transplantation. Blood 102, 3807-3814 (2003)

102. Lam, J. S., Mansour, M. K., Specht, C. A. \& Levitz, S. M. A model vaccine exploiting fungal mannosylation to increase antigen immunogenicity. J. Immunol. 175, 7496-7503 (2005)

This work convincingly demonstrates the added importance of mannosylation for enhancing immunogenicity.

103. Shubitz, L. F. et al. Improved protection of mice against lethal respiratory infection with Coccidioides posadasii using two recombinant antigens expressed as a single protein. Vaccine $\mathbf{2 4}$, 5904-5911 (2006)

104. Tarcha, E. J., Basur, V., Hung, C.-Y., Gardner, M. J. \& Cole G. T. A multivalent protein vaccine against coccidioidomycosis. Infect. Immun. 74, 5802-5813 (2006)

This, and work described in reference 103 demonstrates the enhanced potency of multivalent vaccines.
105. Allendorfer, R., Brunner, G. D. \& Deepe, G. S. Jr. Complex requirements for nascent and memor immunity in pulmonary histoplasmosis. J. Immunol. 162, 7389-7396 (1999).

106. Wüthrich, M., Filutowicz, H. I., Warner, T. \& Klein, B. S . Requisite elements in vaccine immunity to Blastomyces dermatitidis: plasticity uncovers vaccine potential in immune-deficient hosts. J. Immunol. 169 6969-6976 (2002).

107. Cohen, A. D., Boyer, J. D. \& Weiner, D. B. Modulating the immune response to genetic immunization. FASEB $J$. 12, 1611-1626 (1998)

108. Wolff, J. A. et al. Direct gene transfer into mouse muscle in vivo. Science 247, 1465-1468

(1990).

This paper describes the seminal finding that naked DNA injection in muscle leads to gene expression in vivo.

109. McDonnell, W. M. \& Askari, F. K. DNA vaccines. N. Engl. J. Med. 334, 42-45 (1996)

110. Ivey, F. D., Magee, D. M., Woitaske, M. D., Johnston, S. A. \& Cox, R. A. Identification of a protective antigen of Coccidioides immitis by expression library immunization. Vaccine 21, 4359-4367 (2003).

111. Jiang, C., Magee, D. M. \& Cox, R. A. Coadministration of interleukin 12 experssion vector with antigen 2 cDNA enhances induction of protective immunity against Coccidioides immitis. Infect. Immun. 67 5848-5853 (1999).

112. Jiang, C., Magee, D. M., Ivey, F. D. \& Cox, R. A. Role of signal sequence in vaccine-induced protection against experimental coccidioidomycosis. Infect. Immun. 70, 3539-3545 (2002).

113. Jiang, C., Magee, D. M., Quitugua, T. N. \& Cox, R. A. Genetic vaccination against Coccidioides immitis: comparison of vaccine efficacy of recombinant antigen 2 and antigen 2 cDNA. Infect. Immun. 67, 630-635 (1999).

114. Peng, T. et al. Localization within a proline-rich antigen (Ag2/PRA) of protective antigenicity against intection with Coccidioides immitis in mice. Infect. Immun. 70, 3330-3335 (2002).

115. Pinto, A. R., Puccia, R., Diniz, S. N., Franco, M. F. \& Travassos, L. R. DNA-based vaccination against murine paracoccidioidomycosis using the gp 43 gene from Paracoccidioides brasiliensis. Vaccine 18 3050-3058 (2000).

116. Wong, L. P., Woo, P. C., Wu, A. Y. \& Yuen, K. Y. DNA immunization using a secreted cell wall antigen $\mathrm{Mp} 1 \mathrm{p}$ is protective against Peniciliium marneffei infection. Vaccine 20, 2878-2886 (2002).

117. Bozza, S. et al. Dendritic cell-based vaccination against opportunistic fungi. Vaccine 22, 857-864 (2004)

118. Cox, R. A. \& Magee, D. M. Coccidioidomycosis: host response and vaccine development. Clin. Microbiol. Rev. 17, 839 (2004).

This is an excellent review of this topic

119. Donnelly, J. J., Wahren, B. \& Liu, M. A. DNA vaccines: progress and challenges. J. Immunol. 175, 633-639 (2005).

120. Pickering, L. (ed.) Red Book: 2006 Report of the Committee on Infectious Disease. (American Academy of Pediatrics, Elk Grove Village, 2006)

121. Deepe, G. S. Jr. Role of CD8 ${ }^{+}$T cells in host resistance to systemic infection with Histoplasma capsulatum in mice. J. Immunol. 152, 3491-3500 (1994).

122. McAllister, F. et al. T cytotoxic- $1 \mathrm{CD}^{+} \mathrm{T}$ cells are effector cells against pneumocystis in mice. J. Immunol. 172, 1132-1138 (2004).

123. Cano, L. E. et al. Depletion of $\mathrm{CD} 8+\mathrm{T}$ cells in vivo impairs host defense of mice resistant and susceptible to pulmonary paracoccidioidomycosis. Infect. Immun. 68, 352-359 (2000)

124. Huffnagle, G. B., Yates, J. L. \& Lipscomb, M. F. Immunity to a pulmonary Cryptococcus neoformans infection requires both $\mathrm{CD4}^{+}$and $\mathrm{CD} 8{ }^{+} \mathrm{T}$ cells. J. Exp. Med. 173, 793-800 (1991)

125. Mody, C. H., Chen, G.-H., Jackson, C., Curtis, J. L. \& Toews, G. B. Depletion of murine $\mathrm{CD} 8{ }^{+} \mathrm{T}$ cells in vivo decreases pulmonary clearance of a moderately virulent strain of Cryptococcus neoformans. J. Lab. Clin. Med. 121, 765-773 (1993).

126. Wuthrich, M. B., Finkel-Jiminez, B. E. \& Klein, B. S Interleukin 12 as an adjuvant to Wl-1 adhesin immunization augments delayed-type hypersensitivity shifts the subclass distribution of immunoglublin $\mathrm{G}$ antibodies, and enhances protective immunity to Blastomyces dermatitidis infection. Infect. Immun. 68 7172-7174 (2000). 
127. Brandhorst, T. T., Wüthrich, M. B., Filutowicz, H. I. \& Klein, B. S. Targeted gene disruption reveals an adhesin indispensable for pathogenicity of Blastomyces dermatitidis. J. Exp. Med 189, 1207-1216 (2000).

128. Wüthrich, M. B., Filutowicz, H. I. \& Klein, B. S. Mutation of the Wl-1 gene yield an attenuated Blastomyces dermatitidis strain that induces host resistance. J. Clin. Invest. 106, 1381-1389 (2000).

129. Cenci, E., Romani, L., Vecchiarelli, A., Puccetti, P. \& Bistoni, F. Role of L3T4+ lymphocytes in protective immunity to systemic Candida albicans infection in mice. Infect. Immun. 57, 3581-3587 (1989).

130. Walch, H. A. \& Kalvoda, A. Immunization of mice with induced mutants of Coccidioides immitis. I. Characterization of mutants and preliminary studies of their use as viable vaccines. Sabouraudia 173-184 (1971).

131. Shedlock, D. J. \& Shen, H. Requirement for CD4 T cell help in generating functional CD8 T cell memory. Science 300, 337-339 (2003).

132. Sun, J. C. \& Bevan, M. J. Defective CD8 T cell memory following acute infection without CD4 T cell help. Science 300, 339-342 (2003).

133. Gudding, R. \& Naess, B. Vaccination of cattle against ringworm caused by Trichophyton verrucosum. Am. J. Vet. Res. 47, 2415-2417 (1986)

134. Casadevall, A. \& Pirofski, L. A. Exploiting the redundancy in the immune system: vaccines can mediate protection by eliciting 'unnatural' immunity. J. Exp. Med 197, 1401-1404 (2003).

135. Stubbs, A. C. et al. Whole recombinant yeast vaccine activates dendritic cells and elicits protective cellmediated immunity. Nature Med. 7, 625-629 (2001).

136. Noverr, M. C. \& Huffnagle, G. B. Does the microbiota regulate immune responses outside the gut? Trends Microbiol. 12, 562-568 (2004).

137. Noverr, M. C., Falkowski, N. R., McDonald, R. A. McKenzie, A. N. \& Huffnagle, G. B. Development of allergic airway disease in mice following antibiotic therapy and fungal microbiota increase: role of host genetics, antigen, and inteleukin-13. Infect. Immun 73, 30-38 (2005)

138. Noverr, M. C., Noggle, R. M., Toews, G. B. \& Huffnagle, G. B. Role of antibiotics and fungal microbiota in driving pulmonary allergic responses. Infect. Immun. 72, 4996-5003 (2004).

139. Goldman, D. L., Davis, J., Bommarito, F., Shao, X. \& Casadevall, A. Enhanced allergic inflammation and airway responsiveness in rats with chronic Cryptococcus neoformans infection: potential role for fungal pulmonary infection in the pathogenesis of asthma. J. Infect. Dis. 193, 1178-1186 (2006).

140. Pappagianis, D. \& Evaluation of the protective efficacy of the killed Coccidioides immitis spherule vaccine in humans. The Valley Fever Vaccine Study Group. Am. Rev. Respir. Dis. 148, 656-660 (1993).

141. Pappagianis, D. Seeking a vaccine against Coccidioides immitis and serologic studies: expectations and realities. Fungal Genet. Biol. 32, $1-9(2000)$.
142. Ooi, V. E. \& Liu, F. Immunomodulation and anti-cancer activity of polysaccharide-protein complexes. Curr. Med. Chem. 7, 715-729 (2000).

143. Matthews, R., Hodgetts, S. \& Burnie, J. Preliminary assessment of a human recombinant antibody fragment to hsp90 in murine invasive candidiasis. J. Infect. Dis. 171, 1668-1671 (1995).

144. Yang, Q. et al. Prophylactic vaccination with phagedisplayed epitope of $C$. albicans elicits protective immune responses against systemic candidiasis in C57BI/6 mice. Vaccine 23, 4088-4096 (2005).

145. Schaffner, A. et al. In vitro susceptibility of fungi to killing by neutrophil granulocytes discriminates between primary pathogenicity and opportunism. J. Clin. Invest. 78, 511-524 (1986).

146. Allendoerfer, R. \& Deepe, G. S. Blockade of endogenous TNF- $\alpha$ exacerbates primary and secondary pulmonary histoplasmosis by differential mechanisms. J. Immunol. 160, 6072-6082 (1998).

147. Deepe, G. S. Jr., Gibbons, R. \& Woodward, E. Neutralization of endogenous granulocytemacrophage colony-stimulating factor subverts the protective immune response to Histoplasma capsulatum. J. Immunol. 163, 4985-4993 (1999).

148. Zhou, P. et al. IL-12 prevents mortality in mice infected with Histoplasma capsulatum through induction of IFN- $\gamma$. J. Immunol. 155, 785-795 (1995)

149. Huffnagle G. B. et al. Afferent phase production of TNF- $\alpha$ is required for the development of protective T cell immunity to Cryptococcus neoformans. J. Immunol. 157, 4529-4536 (1996)

150. Zerbe, C. S. \& Holland, S. M. Disseminated histoplasmosis in persons with interferon- $\gamma$ receptor 1 deficiency. Clin. Infect. Dis. 41, e38-e41 (2005).

151. Latz, E. et al. TLR9 signals after translocating from the ER to CpG DNA in the lysosome. Nature Immunol. 5, 190-198 (2004)

152. The adjuvant effects of Mycobacterium tuberculosis heat shock protein 70 result from the rapid and prolonged activation of antigen-specific $\mathrm{CD} 88^{+} \mathrm{T}$ cells in vivo. J. Immunol. 169, 5622-5629 (2002)

153. Brown, G. D., Gordon, S. \& Dunn, W. Fungal $\beta$-glucans and mammalian immunity. Immunity 19, 311-315 (2003).

154. Janeway C. A. Jr, Travers, P., Walport, M. \& Shlomchik M. J. Immunobiology: The Immune System in Health and Disease. 341-380 (Garland Publishing, New York, 2001).

155. Tao, M. H., Smith, R. I. F. \& Morrison, S. L. Structura features of human immunoglobulin $\mathrm{G}$ that determine isotype-specific differences in complement activation. J. Exp. Med. 178, 661-667 (1993).

156. Matthews, R. C., Burnie, J. P., Howat, D., Rowland, T. $\S$ Walton, F. Autoantibody to heat-shock protein 90 can mediate protection against systemic candidosis. Immunol. 74, 20-24 (1991).

157. De Bernardis, F. et al. Protective role of antimannan and anti-aspartyl proteinase antibodies in an experimental model of Candida albicans vaginitis in rats. Infect. Immun. 65, 3399-3405 (1997).

158. Spellberg, B. J. et al. Efficacy of the anti-Candida rAls3p-N or rAls $1 \mathrm{p}-\mathrm{N}$ vaccines against disseminated and mucosal candidiasis. J. Infect. Dis. 194, 256-260 (2006)
159. Delgado, N., Xue J Yu, J-J, Hung C. - Y \& Cole C. T A recombinant $\beta$-1,3-glucanosyltransferase homolog of Coccidioides posadasii protects mice against coccidioidomycosis. Infect. Immun. 71, 3010-3019 (2003).

160. Orsborn, K. I. et al. Protein expression profiling of Coccidioides posadasii by two-dimensional differential in-gel electrophoresis and evaluation of a newly recongized peroxisomal matrix protein as a recombinant vaccine candidate. Infect. Immun. $\mathbf{7 4}$ 1865-1872 (2006).

161. Deepe, G. S. Jr, \& Gibbons, R. Protective efficacy of H antigen from Histoplasma capsulatum in a murine model of pulmonary histoplasmosis. Infect. Immun. 69, 3128-3134 (2001)

162 Gomez, F. J., Gomez, A. M. \& Deepe, G. S. Jr. An 80-kilodalton antigen from Histoplasma capsulatum that has homology to heat shock protein 70 induces cell-mediated immune responses and protection in mice. Infect. Immun. 60, 2565-2571 (1992).

163. Scheckelhoff, M. R. \& Deepe, G. S. Jr. Pulmonary V $\beta 4$ $\mathrm{T}$ cells from Histoplasma capsulatum-infected mice respond to a homologue of Sec31 that confers a protective response. J. Infect. Dis. 193, 888-897 (2006).

164. Theus, S. A., Smulian, A. G., Steele, P., Linke, M. J. \& Walzer, P. D. Immunization with the major surface glycoprotein of Pneumocystis carinii elicits a protective response. Vaccine 16, 1149-1157 (1998)

165. Zheng, M. et al. CD4+ T cell-independent vaccination against Pneumocystis carinii in mice. J. Clin. Invest. 108, 1469-1474 (2001)

166. Zheng, M. et al. CD4 ${ }^{+} \mathrm{T}$ cell-independent DNA vaccination against opportunistic infections. J. Clin. Invest. 115, 3536-3544 (2005)

\section{Acknowledgements}

The authors wish to acknowledge research support from grants from the National Institutes of Health.

\section{Competing interests statement}

The authors declare no competing financial interests.

\section{DATABASES}

The following terms in this article are linked online to: Entrez Genome Project: http://www.ncbi.nlm.nih.gov/ entrez/query.fcgi?db=genomeprj

Aspergillus fumigatus | Blastomyces dermatitidis | Candida albicans |Candida glabrata | Candida lusitaniae |Candida tropicalis |Coccidioides immitis |Cryptococcus neoformans | Escherichia coli| Histoplasma capsulatum| Pneumocystis carinii|Saccharomyces cerevisiae | Streptococcus pneumoniae UniProtKB: http://ca.expasy.org/sprot Hsp60|Hsp70|Hsp90|MP65

\section{FURTHER INFORMATION}

Jim E. Cutler's homepage: http://www.chnola-research.org/ faculty/cutler/index.htm

George S. Deepe's homepage: http://intmed.uc.edu/ divisions/infectious_diseases

Bruce S. Klein's homepage: http://www.medmicro.wisc. edu/department/faculty/klein.html Access to this links box is available online. 